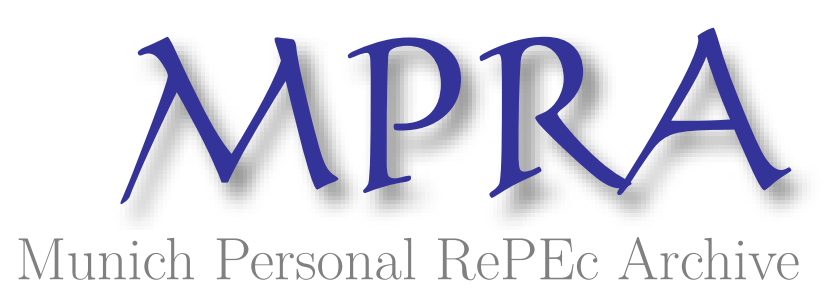

\title{
The Unfinished Business of State-owned Enterprise Reform in the People's Republic of China
}

Holz, Carsten A.

Hong Kong University of Science Technology

2 December 2018

Online at https://mpra.ub.uni-muenchen.de/94093/

MPRA Paper No. 94093, posted 30 May 2019 20:24 UTC 


\title{
The Unfinished Business of State-owned Enterprise Reform in the People's Republic of China
}

\author{
Carsten A. Holz
}

This paper examines the progress of state-owned enterprise (SOE) reform in the People's Republic of China. After defining SOEs and considering their scope of operation within the PRC economy, the focus of the paper is on the major reform waves that followed the deterioration of SOE profitability in the early 1990s. The oil industry serves to illustrate industry-specific SOE reform trends as well as the latest reform developments. Until today, a stable, successful, longterm arrangement of state ownership has remained elusive. SOE reform is incomplete as long as a number of fundamental governance issues are not resolved. But these are difficult to resolve in the context of Party-controlled state-owned enterprises.

Journal of Economic Literature classification:

P00 Economic Systems: General

P31 Socialist Enterprises and Their Transitions

L20 Firm Objectives, Organization, and Behavior: General

P26 Socialist Systems and Transitional Economies: Political Economy; Property Rights

Additionally:

D22 Firm Behavior: Empirical Analysis

L32 Public Enterprises; Public-Private Enterprises

O25 Industrial Policy

O53 Economywide Country Studies: Asia including Middle East

Keywords: State-owned enterprise reform, People's Republic of China, corporate governance, public enterprise management, Chinese Communist Party, state-owned asset management, industrial policy

Carsten A. Holz

Social Science Division

Hong Kong University of Science \& Technology

Clear Water Bay, Kowloon, Hong Kong

carstenholz@gmail.com

http://carstenholz.people.ust.hk/

2 December 2018 


\section{Summary}

State ownership dominated the pre-reform economy of the People's Republic of China (PRC). The transition to a more market-oriented economy from 1978 onward triggered a deterioration in the finances of state-owned enterprises (SOEs) which eventually led to major SOE reforms in 1998-2000. Employment and losses were drastically reduced, and thousands of SOEs were merged or allowed to go bankrupt. In 2003, the remaining SOEs were organized under the newly established central State(-owned) Asset Supervision and Administration Commission (SASAC) or its provincial equivalents. Reform then continued within these institutions. SOEs transformed progressively into formal companies, underwent various forms of restructuring, and began to surrender some of their profit.

By the late 2000s, SOEs came to be seen as instrumental in spearheading state industrial policies, an emphasis that subsequently weakened, with SOEs being crucial to only a few industrial policy areas today. By tightening (Chinese Communist) Party control over SOEs as well as private enterprises, the distinction in industrial policy became one of domestic vs. foreign enterprises rather than SOEs versus private enterprises. Since 2013, new SOE reform initiatives emerged; key among them was the promotion of mixed ownership, a new state capital management system, and various elements of a "modern enterprise system." Bbut progress has been slow. By 2018, SOE reform discussions centered on strengthening Party control over SOEs and making SOEs "stronger, better, and bigger."

State ownership today accounts for little more than one-third of gross domestic product (GDP) and it is concentrated in typical public goods sectors such as public facilities, education, health, and public management. In manufacturing, SOEs account for only one-quarter of assets. The state has a monopoly position in petroleum and natural gas extraction, the tobacco industry, and electricity production/distribution and water supply. The state controls all banks and owns the three major airlines and all three telecommunication providers.

Questions persist about the objectives of SOEs, ownership rights over SOEs, and SOE supervision. SOE objectives are ambiguous. SASAC's ownership of the center's state-owned conglomerates is exceedingly weak in that SASAC does not appoint key personnel of its companies, has only limited claims to SOE profits, has little regulatory authority, and seems preoccupied primarily with resolving problems in individual SOEs and supporting top-level industry priorities. To some extent, SASAC appears to be a smokescreen for the actual channels of authority and a convenient location in which to deposit (and make invisible) SOE problems. Supervision within SOEs is fraught when basic control mechanisms established by the Company Law are sidestepped through Party precedence. Adoption of the formal company system and mixed ownership reform have allowed (re-)capitalization of listed SOEs by means other than the state budget and state bank lending and thereby freed the state of some of the liability for SOE failure, but it has not necessarily led to good governance.

Corporate governance in the PRC is ultimately a question of how the Party is to manage the stateowned Party-controlled enterprises in an environment where Western principles of good corporate governance are not an option. While past achievements may be impressive, current SOE performance suggests a dilemma in that an increasingly sophisticated economy exceeds the steering capacity of an authoritarian Leninist regime, while the correspondingly mature institutions needed to support a modern economy and to advance economic growth are missing. 


\section{Table of Contents}

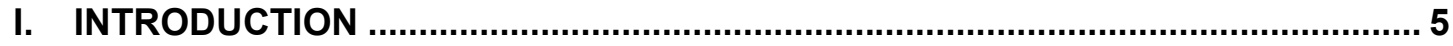

II. STATE-OWNED ENTERPRISE DEFINITION, EXTENT, AND PERFORMANCE... 7

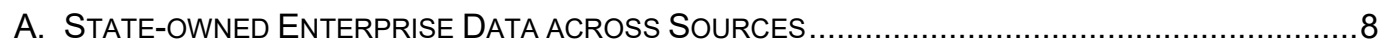

B. THE EXTENT OF STATE OWNERSHIP ACROSS THE ECONOMY ........................................... 10

C. StATE-OWNEd ENTERPRISE PROfitABILITY (FINANCE MINISTRY DATA) ...........................11

III. STATE-OWNED ENTERPRISE REFORMS …................................................... 14

A. StATE-OWNed ENTERPRISE Reform Program OF 1998-2000 .....................................14

B. State AsSet Supervision ANd Administration Commission, From 2003 ONWARd .......16

C. DisParate StrandS OF State-OWNEd ENTERPRISE Policy IN THE 2010s ........................18

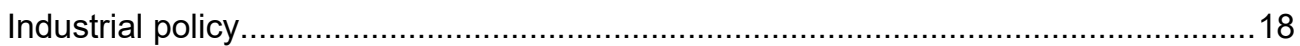

State-owned enterprise reforms since the Third Plenum of 2013 ..........................19

Role of the Chinese Communist Party .................................................................22

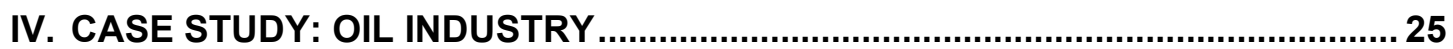

A. REFORM STAGES

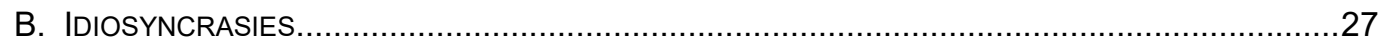

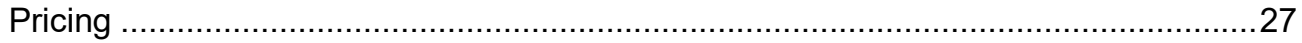

Appointments and appointment authority ...................................................28

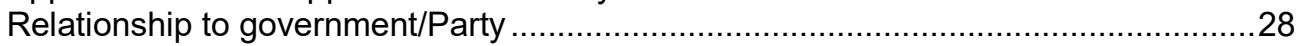

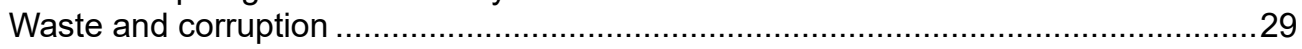

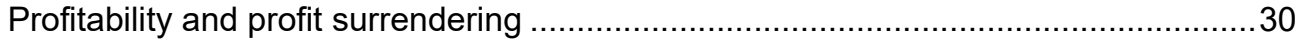

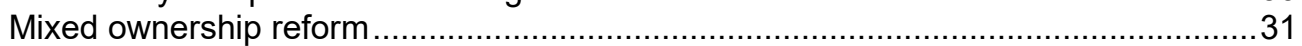

V. CURRENT CHALLENGES OF STATE OWNERSHIP .......................................... 31

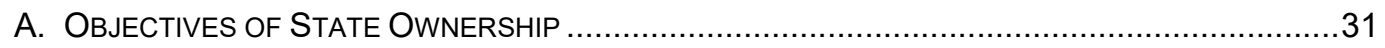

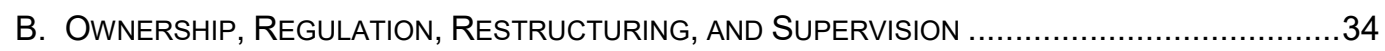

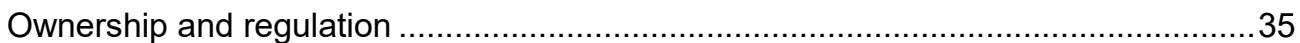

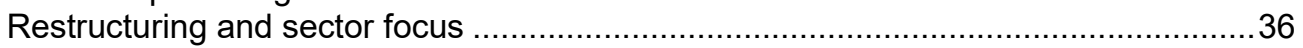

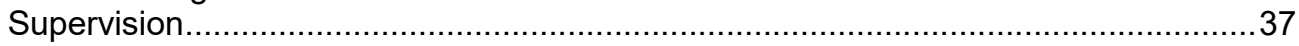

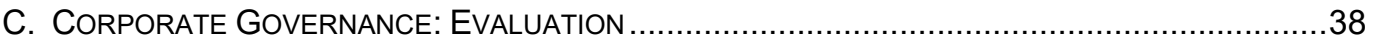

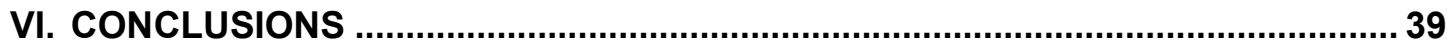




\section{Figures}

Figure 1: Industrial State-owned Enterprise Profit (and Tax) Measures

\section{Tables}

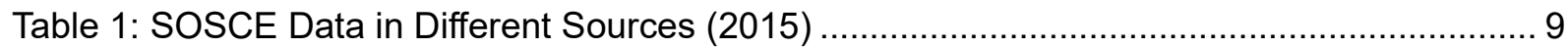

Table 2. SOSCE Share in Gross Domestic Product (2015) ..............................................11

Table 3: Number of State Enterprises and their Performance (Finance Ministry Data) ............. 12

Table 4: State Enterprises by Sector (2015, Finance Ministry Data) ........................................ 13

Table 5: Fortune Global 500 List 2018, Sinopec and PetroChina ........................................... 31

\section{Appendices}

Appendix 1. State-owned Enterprise Share in Gross Domestic Product

Appendix 2. Choice of Performance Indicator

\section{ABBREVIATIONS}

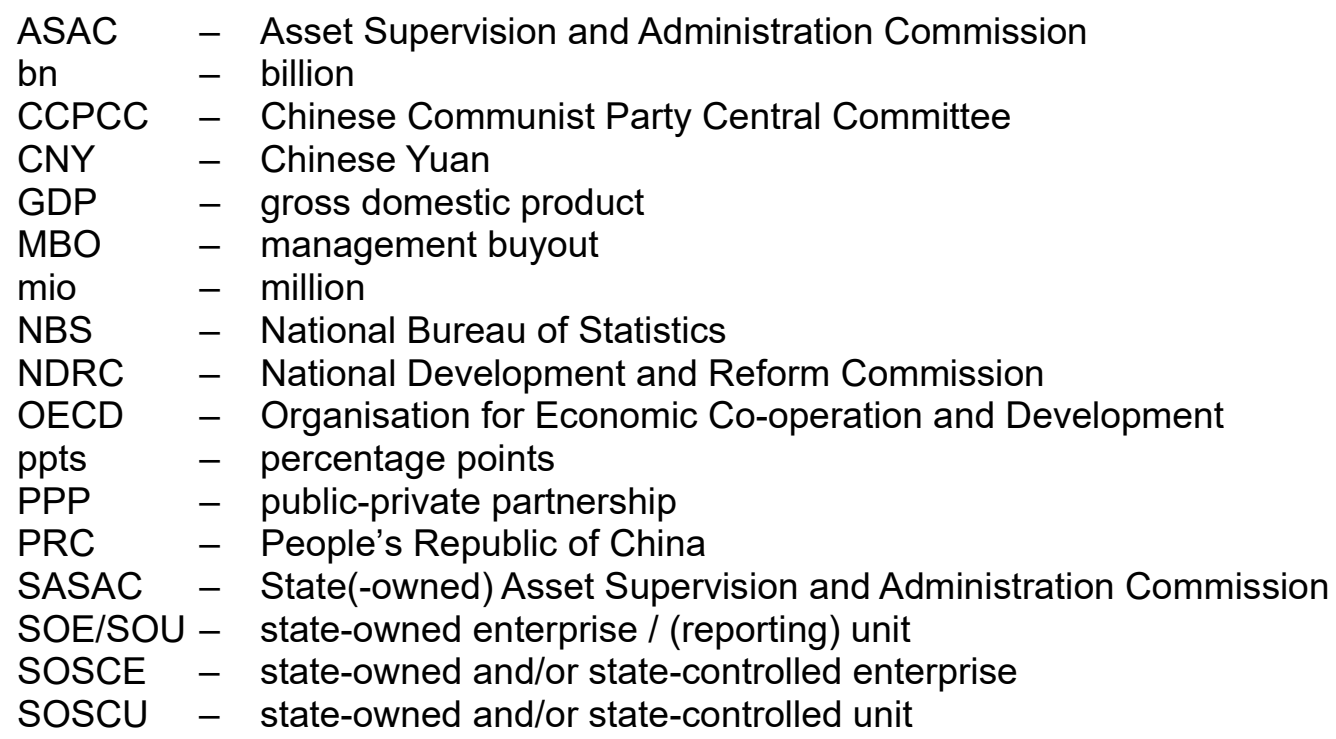




\section{INTRODUCTION}

1. State-owned enterprises (SOEs) have played a major and, over time, changing role in the economic development of the People's Republic of China (PRC). This paper examines the evolving role of SOEs in the PRC and evaluates SOE reform measures in light of SOE performance. It elaborates on potential future reforms with an eye to how to reform SOEs to maintain their economic viability and competitiveness and to enhance their contribution to longterm economic growth.

2. In the pre-reform (pre-1978) PRC economy, state ownership dominated. After the founding of the PRC in 1949, private enterprises and Kuomintang (Nationalist) enterprises were nationalized, and a new economy-wide industrial base in state ownership was established. Between 1957 and 1977, SOEs and the planned economy defined the government and its operations. The government ran the economy via physical output (and investment) plans. SOEs directly accounted for approximately half of government budget revenues and expenditures. In the reform period (since 1978), the commanding position of SOEs was challenged with the introduction of a dual track price system (plan and market prices for one and the same good) and eventually the elimination of most plan prices in the early 1990s, the emergence of competitive rural collectiveowned enterprises, an end to output planning, and changes to SOE financing mechanisms,

3. By the early 1990s, financial measures showed SOE performance to be deteriorating rapidly. In the case of industry-i.e., mining, manufacturing, and utilities-SOE profits throughout the prereform period (1949-1977) were equivalent to approximately $10 \%$ to $15 \%$ of gross domestic product (GDP), and together with taxes to approximately $20 \%$ of GDP (Figure 1). In the reform period, these percentages declined drastically. Profits then recovered to a level equivalent to just $4 \%$ of GDP in 2007, before falling again and ending the period in 2016 at $2 \%$. The history of SOE performance in the PRC is thus a varied one and linked intricately to economic transition and reform measures across the economy.

4. A large body of literature examines various aspects of SOEs in the PRC. For example, Hong and Nong (2013) argue that SOEs are in dire need of reform. According to their calculations at the time, the profits of only two SOEs (China National Petroleum Corporation and China Mobile) account for one-third of all SOE profits. If SOEs had to pay market rent on land, $67 \%$ of their nominal profit would be eliminated. If SOEs had to pay a market interest rate of $4.68 \%$ on their borrowing instead of the interest rate of $1.6 \%$ they actually paid, another $47 \%$ of their nominal profit would disappear. The authors wanted to break the SOEs' monopoly over bureaucratic interests and strictly regulate the conduct of SOEs. Lam et al. (2017), in a working paper on PRC "zombie" firms-firms with, among others, three subsequent years of losses-point out that SOEs account for half of total debt and about one-third of employment in zombie firms. ${ }^{1}$

5. In contrast, authors such as Cui (2011) and Huang (2011) see an important role for the state in economic development. SOEs can be a reservoir of value and a source of recurrent income for the state, more so than if economic activity were left to the private sector. Land plays a special role: Harking back to Sun Yat-Sen (the founding father of the Republic of China, in 1912), the increase in land value that is not a result of the private owner's effort should go to the public, i.e., an argument is made for the state to retain control over land. Finally, in this view, the state is particularly well suited to reorganize SOEs rather than to let their value dissipate via low-priced sell-offs.

1 The authors report that about 2,000 central SOEs (with total assets of about $4 \%$ of GDP) and more than 7,000 local SOEs have officially been declared zombie firms. For perspective, total SOE assets in 2016 were equivalent to $56 \%$ of GDP (Statistical Yearbook 2017, p. 56; Industry Statistical Yearbook 2017, p. 3). 


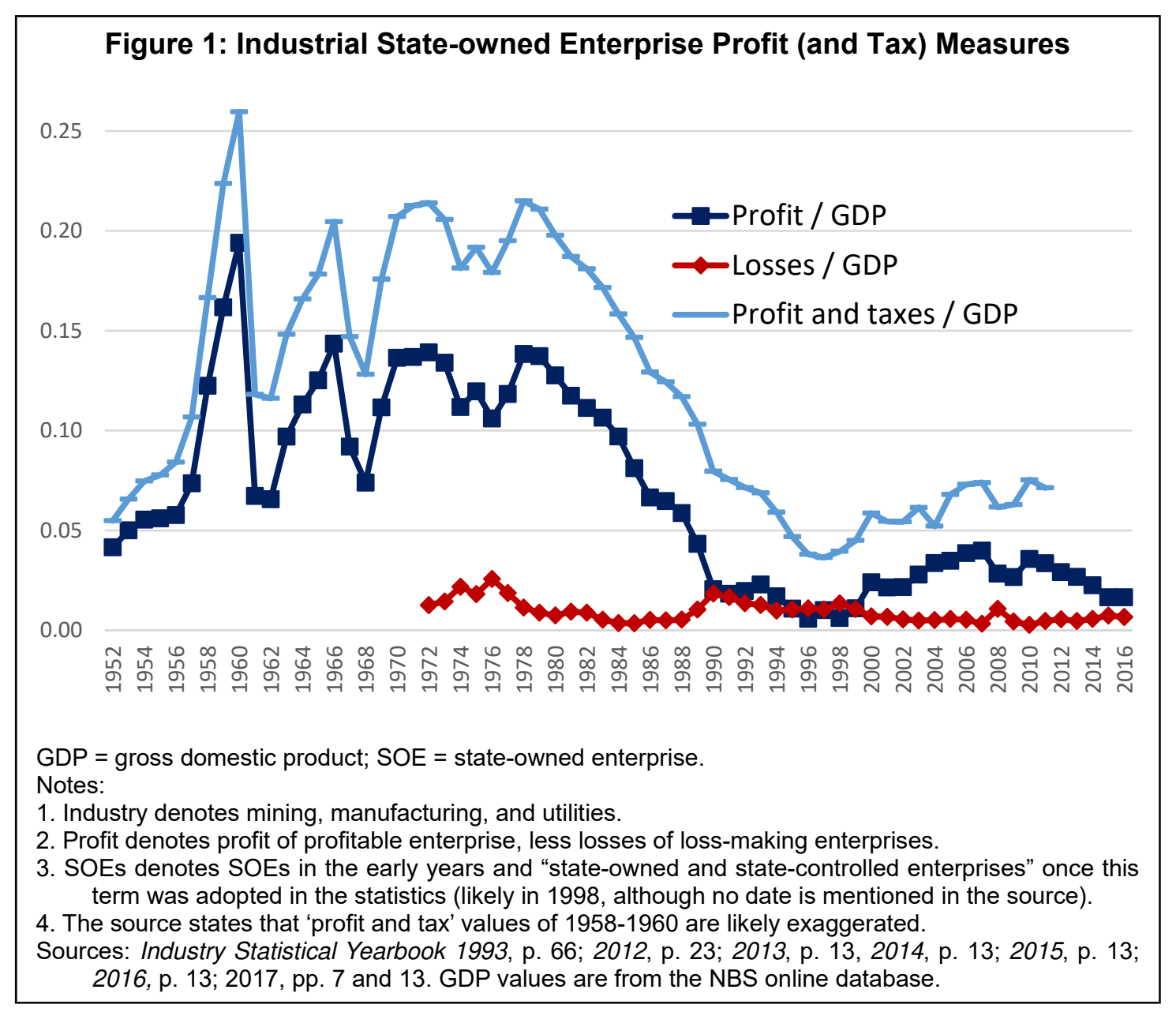

6. Another body of literature has noted that SOE efficiency growth (typically in a neoclassical analytical framework) tends to lag behind efficiency growth in other ownership forms (for example, Brandt and Zhu, 2010). But it can also be argued that the performance of SOEs, particularly their financial performance as measured by profitability, does not necessarily reflect some intrinsic shortcoming of SOEs but the economic and political constraints these enterprises face (Holz, 2003).

7. In an earlier study, Xu and Wang (1999) find that a listed firm's profitability is positively correlated with the fraction of legal person shares (shares by state-owned entities), but uncorrelated or negatively correlated with the fraction of (outright) state shares; i.e., ministries holding stakes in listed SOEs may not be beneficial to the listed SOEs' profitability, but SOEs and other state units holding stakes in the listed SOEs is. In a study not specific to the PRC, Dewenter and Malatests (2001) find that SOEs have inferior profitability (perhaps for good social and political reasons), but that privatization does not improve profitability after privatization; profitability improves over the three years before privatization. In other words, the government's preparation for privatization improves profitability, or, in yet other words, SOEs could be more profitable if the government chooses to make profitability a priority, and privatization may at best serve to perpetuate profitability gains. The authors also find that SOEs tend to use more labor than their private counterparts and are more leveraged. 
8. Lardy (2014) stresses the role of private ownership and markets over state ownership and state-led industrial policy for the PRC's economic growth. In contrast, the Trump administration as of 2018 seems to believe that the PRC's industrial policy and state ownership are particularly beneficial to the country's (economic and political) rise.

9. This paper takes a broader view of the evolving role of SOEs in the PRC and evaluates current SOE reform measures and performance. The following section presents summary data on the extent and performance of SOEs in the PRC. The subsequent sections discuss the waves of SOE reforms since the 1980s and their effects, present a case study of the oil industry, and evaluate current challenges for state ownership. The final section concludes and examines reform options going forward.

\section{STATE-OWNED ENTERPRISE DEFINITION, EXTENT, AND PERFORMANCE}

10. A first distinction is between state-owned "units" (SOUs) and state-owned "enterprises" (SOEs). SOUs comprise all SOEs plus state-owned facilities (shiye danwei), such as universities, and state-owned administrative organs (xingzheng danwei), such as government departments and their immediate extensions.

11. The focus frequently is on SOEs only. The definition of state-owned enterprises in the PRC depends on the institution involved: ${ }^{2}$

- The National Bureau of Statistics (NBS) classifies state enterprises according to their registration modus.

- The Finance Ministry in its statistics covers state enterprises of which it is the ultimate owner.

- The central State(-owned) Asset Supervision and Administration Commission (SASAC) provides summary statistics on the state enterprises under its supervision and administration and those under provincial supervision and administration, i.e., on the bulk of non-financial state enterprises, that are, theoretically, a subset of the previous category.

12. The NBS and the Finance Ministry statistics differ if some state enterprises are not formally registered, or are not regarded by the Finance Ministry as under its remit. The Finance Ministry statistics cover SOEs in all sectors of the economy, while the NBS provides detailed data only for SOEs in industry (and to a limited extent in a few other sectors).

13. The NBS statistics on SOEs, especially those on SOEs in industry (Figure 1), tend to be the most widely used in the literature. The NBS definition of industrial SOEs has changed over time. A first innovation occurred after the Company Law was introduced in 1993. Through 1998, industrial SOEs then comprised:

- all traditional SOEs (all unreformed SOEs),

- joint enterprises between two or more SOEs and joint enterprises between an SOE and a collective-owned enterprise (together accounting for a tiny fraction of industrial output), and

- solely state-owned limited liability companies.

Since 1998, the NBS uses the term industrial "state-owned and state-controlled enterprises"

2 OECD (2015, p. 14) defines SOEs as "any corporate entity recognised by national law as an enterprise, and in which the state exercises ownership." 
(SOSCEs) to denote the aggregate of

- pre-1998 definition SOEs (comprising the three categories above), and

- all (other) shareholding companies (i.e., limited liability companies and stock companies) in which the state has a controlling share. ${ }^{3}$

Since 1998, the term "state-owned enterprises" (SOEs) in the NBS statistics tends to refer only to traditional (i.e., unreformed) SOEs and thereby, in contrast to the practice before 1998, excludes joint enterprises involving an SOE as well as solely state-owned limited liability companies. ${ }^{4}$

14. In the following, the term "SOEs" will be used as the overarching term that captures both the pre-1998 definition SOEs and the SOSCE category as defined since 1998. When necessary for clarity in a particular context, the precise terminology is used, such as "traditional (or: unreformed) SOEs," and "SOSCEs." When presenting statistics that labeled "SOSCEs" in the source, that term is retained rather than switching to the (by agreement) equivalent generic term "SOEs."

\section{A. State-owned Enterprise Data across Sources}

15. Table 1 presents 2015 sector data on SOSCE (or: SOE) enterprise numbers as well as on their assets, equity, and employment. These data are taken from three sources: the Finance Ministry (abbreviated in the table "FM"), excluding the finance sector, SASAC, and NBS (for above-norm industrial SOSCEs). ${ }^{5}$

16. Focusing on industry (mining, manufacturing, and utilities), for which all three sources provide data, the employment values match reasonably well (around 17mio). The three sources diverge significantly in the case of enterprise numbers (the Finance Ministry with 42,816 industrial SOEs reports about $20 \%$ more enterprises than SASAC, and about twice as many as the NBS). SASAC reports almost twice as much assets and equity as the Finance Ministry and the NBS do. ${ }^{6}$

${ }^{3}$ State-controlled companies come in two forms. Absolute state control (guoyou juedui konggu) implies that the state holds more than $50 \%$ of total capital (ziben). Relative state control (guoyou xiangdui konggu) implies that although the state holds less than $50 \%$ of total capital, (i) the state share is relatively large compared to the shares of other ownership categories, i.e., "relative state control" in its narrow meaning (xiangdui konggu), or (ii) even though one or more other ownership categories have a larger capital share than the state, the state in effect holds the control rights by agreement (xieyi kongzhi). Both forms of state-controlled companies are included in the definition.

4 The NBS has implemented similar classifications and transitions in the definition of "SOEs" for other economic sectors. The 2013 economic census yielded registration-based data on all legal person units in the PRC; the statistics do not provide the aggregate SOSCE measure. The registration-based classification includes a stock company category, which, however, does not come with a state vs. non-state breakdown.

52015 is the most recent year for which SASAC data are available. The finance sector data reported by SASAC likely reflect minor financial operations of otherwise non-financial SOEs. In the NBS coverage, above-norm industrial enterprises are enterprises with annual main business revenue in excess of CNY 20 mio.

${ }^{6}$ It could be that SASAC does not net out the non-state share of SOE assets and equity while the Finance Ministry and the NBS may do (perhaps in proportion to equity shares). SASAC's reported national total assets and equity also exceed the Finance Ministry figure, by about one-third; but SASAC also reports a second figure for national total assets and equity (with identical label "total"), which is smaller than its first figure and closer to (and below) the Finance Ministry values, and might reflect SASAC's estimate of the state share only. 


\begin{tabular}{|c|c|c|c|c|c|c|c|c|c|c|c|c|}
\hline \multicolumn{13}{|c|}{ Table 1: SOSCE Data in Different Sources (2015) } \\
\hline & \multicolumn{3}{|c|}{ Enterprises } & \multicolumn{3}{|c|}{ Assets (bn yuan) } & \multicolumn{3}{|c|}{ Equity (bn yuan) } & \multicolumn{3}{|c|}{ Employment (thousand) } \\
\hline & $\mathrm{FM}$ & SASAC & NBS & FM & SASAC & NBS & FM & SASAC & NBS & FM & SASAC & NBS \\
\hline $\begin{array}{l}\text { National total } \\
\text { Alternative total (unexplained total) }\end{array}$ & 167,399 & 124,966 & & 140,683 & $\begin{array}{l}183,839 \\
119,912\end{array}$ & & 48,241 & $\begin{array}{l}70,422 \\
39,860\end{array}$ & & 36,506 & 30,946 & \\
\hline 1. Agriculture & 6,954 & 2,838 & & 1,079 & 893 & & 384 & 383 & & 2,614 & 450 & \\
\hline 1.1 Farming & 3,033 & 1,039 & & 643 & 388 & & 217 & 190 & & 1,725 & 220 & \\
\hline 1.2 Forestry & 1,546 & 453 & & 187 & 130 & & 72 & 42 & & 658 & 116 & \\
\hline 1.3 Husbandry & 712 & 0 & & 57 & 0 & & 23 & 0 & & 82 & 0 & \\
\hline 1.4 Fishery & 321 & 0 & & 23 & 0 & & 8 & 0 & & 33 & 0 & \\
\hline 1.5 Implicit residual & 1,342 & 1,346 & & 169 & 375 & & 63 & 151 & & 116 & 114 & \\
\hline 2. Industry* & 42,816 & 36,771 & 19,273 & 38,210 & 62,101 & 39,740 & 15,671 & 26,485 & 15,126 & 17,653 & 16,721 & 17,778 \\
\hline 2.1 Coal & 2,422 & 2,341 & 937 & 3,741 & 6,520 & 3,980 & 1,105 & 1,965 & 1,178 & 3,040 & 2,858 & 3,210 \\
\hline 2.2 Petroleum, petrochemicals & 771 & 812 & 304 & 4,537 & 11,343 & 3,214 & 3,478 & 6,474 & 1,550 & 1,940 & 1,797 & 1,169 \\
\hline 2.3 Metallurgical industry & 2,596 & 2,606 & & 4,721 & 7,808 & & 1,255 & 2,699 & & 2,004 & 1,853 & \\
\hline 2.4 Building materials & 2,959 & 2,841 & & 995 & 1,624 & & 343 & 609 & & 609 & 563 & \\
\hline 2.5 Chemical industry & 3,081 & 2,749 & 1,171 & 2,071 & 3,243 & 2,018 & 612 & 1,138 & 641 & 1,119 & 1,047 & 873 \\
\hline 2.6 Forest industry & 153 & 96 & & 17 & 20 & & 2 & 6 & & 20 & 12 & \\
\hline 2.7 Foods & 2,015 & 1,210 & 1,000 & 347 & 366 & 356 & 112 & 144 & 129 & 302 & 269 & 323 \\
\hline 2.8 Tobacco & 146 & 438 & 106 & 897 & 155 & 908 & 695 & 61 & 679 & 206 & 161 & 201 \\
\hline 2.9 Textiles & 485 & 724 & 403 & 123 & 549 & 146 & 43 & 307 & 64 & 185 & 273 & 275 \\
\hline 2.10 Pharmaceuticals & 864 & 7,024 & 422 & 363 & 7,120 & 389 & 213 & 3,119 & 220 & 301 & 2,902 & 306 \\
\hline 2.11 Machinery industry & 7,646 & 1,336 & 2,217 & 4,687 & 3,049 & 4,596 & 1,938 & 1,549 & 1,815 & 2,687 & 1,091 & 2,356 \\
\hline of which: automobiles & 1,317 & 1,289 & 741 & 1,838 & 2,457 & 2,738 & 911 & 995 & 1,149 & 914 & 834 & 1,249 \\
\hline 2.12 Electronics & 1,844 & 1,688 & 613 & 1,066 & 1,449 & 1,177 & 489 & 713 & 509 & 641 & 662 & 703 \\
\hline 2.13 Power industry & 7,126 & 6,576 & 4,397 & 9,748 & 15,612 & 11,141 & 3,332 & 6,444 & 4,195 & 2,124 & 2,133 & 2,483 \\
\hline 2.14 Municipal public goods, utilities & 5,525 & 3,860 & & 2,219 & 2,444 & & 900 & 1,114 & & 863 & 639 & \\
\hline 2.15 Other industry & 5,183 & 2,517 & & 2,678 & 1,393 & & 1,155 & 697 & & 1,613 & 718 & \\
\hline 2.16 Implicit residual, NBS: All else & 0 & -47 & 7703 & 0 & -592 & 11,815 & 0 & -554 & 4,145 & -1 & -257 & 5,880 \\
\hline 3. Construction & 10,343 & 8,988 & & 10,055 & 13,781 & & 2,920 & 4,302 & & 2,700 & 3,872 & \\
\hline 4. Geological prosp.,water conservancy & 1,714 & 892 & & 774 & 663 & & 457 & 361 & & 155 & 119 & \\
\hline 5. Transport and storage & 17,152 & 8,089 & & 18,904 & 14,274 & & 6,825 & 6,624 & & 4,903 & 2,610 & \\
\hline 5.1 Railway transport & 1,317 & 212 & & 6,463 & 538 & & 2,331 & 324 & & 1,962 & 66 & \\
\hline 5.2 Road transport & 4,300 & 3,780 & & 6,836 & 8,675 & & 2,450 & 3,707 & & 1,855 & 1,661 & \\
\hline 5.3 Water transport & 1,580 & 1,439 & & 1,143 & 1,965 & & 549 & 962 & & 202 & 195 & \\
\hline 5.4 Air transport & 632 & 590 & & 1,202 & 1,438 & & 554 & 673 & & 329 & 383 & \\
\hline 5.6 Implicit residual & 2,099 & 2,068 & & 1,062 & 1,658 & & 634 & 957 & & 238 & 305 & \\
\hline 5.5 Storage (SASAC: new item) & 7,224 & 3,251 & & 2,199 & 2,178 & & 307 & 351 & & 317 & 179 & \\
\hline 6. Post and telecommunications & 1,428 & 687 & & 3,599 & 6,069 & & 2,193 & 4,325 & & 1,662 & 1,193 & \\
\hline 7. Trade and catering & 25,317 & 19,096 & & 6,574 & 10,235 & & 1,976 & 3,242 & & 2,147 & 2,012 & \\
\hline 8. Real estate & 16,152 & 15,280 & & 13,899 & 19,230 & & 3,865 & 5,553 & & 788 & 856 & \\
\hline 9. Information technology services & 2,008 & 1,673 & & 379 & 366 & & 164 & 180 & & 213 & 194 & \\
\hline 10. Social services & 26,232 & 17,961 & & 23,638 & 29,402 & & 11,168 & 14,703 & & 1,990 & 1,453 & \\
\hline 11. Health, sports, welfare & 800 & 556 & & 175 & 165 & & 72 & 50 & & 116 & 115 & \\
\hline 12. Education, culture, broadcast. & 6,139 & 1,906 & & 767 & 263 & & 466 & 143 & & 442 & 134 & \\
\hline 13.Scientific research, techn. services & 8,111 & 5,272 & & 1,395 & 1,591 & & 559 & 681 & & 736 & 718 & \\
\hline 14. Admin. organs, mass org., others & 2,233 & & & 21,234 & & & 1,521 & & & 389 & & \\
\hline SASAC: Finance & & 1,627 & & & 22,535 & & & 2,989 & & & 427 & \\
\hline SASAC: Others & & 79 & & & 92 & & & 51 & & & 3 & \\
\hline \multicolumn{13}{|l|}{ Enterprise size } \\
\hline (1) Large & & 8,377 & & & 89,706 & & & 33,343 & & & 19,604 & \\
\hline (2) Medium-sized & & 25,085 & & & 34,216 & & & 11,562 & & & 7,468 & \\
\hline (3) Small & & 41,759 & & & 30,001 & & & 12,037 & & & 3,226 & \\
\hline (4) Micro & & 49,745 & & & 29,916 & & & 13,480 & & & 759 & \\
\hline \multicolumn{13}{|l|}{ Organizational form } \\
\hline (1) Company system & & 116,142 & & & 174,483 & & & 66,504 & & & 28,318 & \\
\hline of which: solely state-invested & & 33,417 & & & 61,670 & & & 28,051 & & & 7,271 & \\
\hline (2) Not company system & & 8,824 & & & 9,357 & & & 3,917 & & & 2,739 & \\
\hline Profit & & & & & & & & & & & & \\
\hline (1) Profitable & & 78,900 & & & 145,006 & & & 58,823 & & & 21,827 & \\
\hline (2) Loss-making & & 46,066 & & & 38,833 & & & 11,598 & & & 9,230 & \\
\hline Supervision / administration & & & & & & & & & & & & \\
\hline (1) SASAC & & 42,411 & & & 47,581 & & & 15,850 & & & 14,186 & \\
\hline (2) Local ASACs & & 82,555 & & & 72,331 & & & 24,010 & & & 16,760 & \\
\hline Regions (do not add up) & & & & & & & & & & & & \\
\hline (1) Eastern sea-borders & & 65,237 & & & 105,442 & & & 41,969 & & & 14,216 & \\
\hline (2) Middle central & & 23,854 & & & 28,967 & & & 10,439 & & & 8,215 & \\
\hline (3) Western remote & & 28,865 & & & 36,941 & & & 13,016 & & & 8,096 & \\
\hline Economic functions & & & & & & & & & & & & \\
\hline (1) Basic industries & & 37,522 & & & 77,944 & & & 33,791 & & & 16,418 & \\
\hline (2) General production \& processing & & 22,326 & & & 21,101 & & & 8,579 & & & 8,563 & \\
\hline (3) Business services and others & & 65,118 & & & 84,794 & & & 28,052 & & & 6,076 & \\
\hline $\begin{array}{l}\text { SOSCE = state-owned and state-contr } \\
\text { Administration Commission; NBS = Natio } \\
\text { * NBS industry data come in approximat } \\
\text { classification. Specifically, the NBS indus } \\
\text { Extraction of Petroleum and Natural Ga } \\
\text { Materials and Chemical Products; } 2.7 \\
\text { Manufacture of Textile; Manufacture of T } \\
\text { Footwear; } 2.10 \text { Manufacture of Medicines } \\
\text { of Automobiles; } 2.11 \text { sub-category Manu } \\
2.13 \text { Production and Supply of Electric Po } \\
\text { Sources: Fiscal Yearbook 2016, SASAC }\end{array}$ & $\begin{array}{l}\text { trolled ent } \\
\text { onal Burea } \\
\text { ately } 40 \mathrm{se} \\
\text { ustry categ } \\
\text { as; Proces } \\
\text { Manufactc } \\
\text { Textile, We } \\
\text { s; } 2.11, \mathrm{Ma} \\
\text { ufacture of } \\
\text { Ower and } \\
\text { Yearbook }\end{array}$ & $\begin{array}{l}\text { terprise (c } \\
\text { au of Statis } \\
\text { ector cates } \\
\text { gories mat } \\
\text { ssing of Pe } \\
\text { ure of Foc } \\
\text { earing App } \\
\text { anufacture } \\
\text { f Automobi } \\
\text { Heat Pow } \\
2016, \text { NB }\end{array}$ & $\begin{array}{l}\text { gories, } \\
\text { tched in } \\
\text { etroleun } \\
\text { od; Proc } \\
\text { parel an } \\
\text { of Gene } \\
\text { iles; } 2.1 \\
\text { ver; } 2.16\end{array}$ & $\begin{array}{l}\text { ); FM = } \\
\text { nployment } \\
\text { which are } \\
\text { to the FM } \\
\text { n, Coking } \\
\text { cessing of } \\
\text { d Accesso } \\
\text { ral Purpos } \\
2 \text { Manufa } \\
\text { All Others } \\
\text { ase (abov }\end{array}$ & $\begin{array}{l}\text { Finance } \\
\text { t: = year-e } \\
\text { aggregate } \\
\text { 1/SASAC } \\
\text { and Proc } \\
\text { f Food frc } \\
\text { ries; Man } \\
\text { se Machin } \\
\text { cture of C } \\
\text { s. }\end{array}$ & $\begin{array}{l}\text { ed as m } \\
\text { classifica } \\
\text { cessing o } \\
\text { om Agric } \\
\text { hufacture } \\
\text { eery; Man } \\
\text { Jomputer }\end{array}$ & $\begin{array}{l}\text { loyment } \\
\text { luch as } p \\
\text { ation her } \\
\text { of Nucle } \\
\text { cultural } P \\
\text { of Leath } \\
\text { nufacture } \\
\text { rs, Comn }\end{array}$ & $\begin{array}{l}\text { (in the cas } \\
\text { bossible he } \\
\text { e are } 2.1 \\
\text { ar Fuel; } 2 . \\
\text { Products; } \\
\text { her, Fur, F } \\
\text { of Special } \\
\text { nunication }\end{array}$ & $\begin{array}{l}\text { lere to } \mathrm{m} \\
\text { Mining } \\
2.5 \mathrm{Manu} \\
2.8 \mathrm{Man} \\
\text { =eather a } \\
\text { al Purpos } \\
7 \text { and Otl }\end{array}$ & $\begin{array}{l}\text { d) Asset } \\
\text { l data: sta } \\
\text { natch the } \\
\text { and Was } \\
\text { ufacture } \\
\text { nufacture } \\
\text { and Rela } \\
\text { se Machin } \\
\text { ther Elect }\end{array}$ & $\begin{array}{l}\text { Supervisi } \\
\text { aff and wor } \\
\text { e FM and } \\
\text { shing of C } \\
\text { of Raw Cr } \\
\text { e of Tobac } \\
\text { ated Produ } \\
\text { inery; Manu } \\
\text { tronic Equ }\end{array}$ & $\begin{array}{l}\text { ion and } \\
\text { rkers). } \\
\text { SASAC } \\
\text { Soal: } 2.2 \\
\text { hemical } \\
\text { cco; } 2.9 \\
\text { ucts and } \\
\text { ufacture } \\
\text { uipment; }\end{array}$ \\
\hline
\end{tabular}


17. Overall, the employment data may yet be the most meaningful. For perspective, in 2015 SOEs (not including employment in non-enterprise state units) accounted for approximately $5 \%$ of economy-wide employment. ${ }^{7}$

18. Approximately half of SOE employment is in industry. Of employment in industrial SOEs, approximately half is in the coal industry, pharmaceutical industry or machinery industry (SASAC or Finance Ministry data), and power industry, with another quarter in the petroleum, metallurgical, and chemical industry. ${ }^{8}$ Construction, transport and storage, post and telecommunications, trade and catering, and social services account for approximately one-third of total SOE employment. Employment in the sector "government, (Chinese Communist) Party, mass organizations and others" is only $1 \%$ of the total (while this sector accounts for $16 \%$ of SOE assets); the rationale likely being that the data only cover "enterprises" and thus exclude "non-enterprise units."

19. The SASAC data come with further distinctions. Two-thirds of employment is in large enterprises (which account for only $7 \%$ of all SASAC SOEs but approximately half of assets and equity). More than $90 \%$ of SOEs (by any measure) are organized as companies, of which less than half are solely state-owned. One-third of SOEs are loss-making. About one-third of SOEs are organized under SASAC (rather than local ASACs), although with regard to employment the central and local shares are about equal. More than half of SOEs are located in the coastal Eastern region rather than in the central or Western regions. Approximately half of SOE employment is in basic industries, with the remainder split between "general production and processing" and "business services and others." The data imply that each of the approximately 100 SASAC conglomerates in 2015 comprised 1,250 enterprises on average.

\section{B. The Extent of State Ownership across the Economy}

20. Official data by ownership across the economy are not available for output measures or for employment, nor for balance sheet or profit and loss account measures. Value-added by ownership can be derived or estimated sector by sector across the 19 economic sectors from which the NBS derives the PRC's gross domestic product (GDP) value (Table 2). The coverage is all state-owned productive units, not only in those officially labeled "enterprises." The share of derived/estimated value-added in state-owned and state-controlled units (SOSCUs) varies greatly across sectors. While the SOSCU value-added share approaches unity in public management, finance, and utilities, its share in manufacturing is only $14 \%$ and in agriculture around $2 \%$. Overall, SOSCUs account for approximately $39 \%$ of GDP.

21. Finance accounts for most of the value-added produced in state ownership at $19 \%$. Manufacturing follows at $11 \%$ and then come the typical public goods sectors-public management (10\%), education ( $8 \%$ ) and utilities $(5 \%)$-and potentially competitive sectors such as construction (7\%), trade (6\%), and transport, storage and post $(6 \%)$.

22. Further, dispersed data on the scope of state ownership are available. As of early 2018 , SOEs reportedly account for $40 \%$ of the PRC's stock market valuation. Of the central government's SOE portfolio, $63 \%$ is listed on the stock market. SOEs account for $45 \%$ of all debt in the PRC (and two-thirds of the non-financial corporate sector's debt); total SOE debt stands at approximately $115 \%$ of GDP. The state accounts for approximately $15 \%$ of employment (presumably this includes employment in state-owned units that are not "enterprises"). Of the central government's

7 This percentage is obtained by comparing the Finance Ministry employment figure of 36.506 mio to the nationwide employment figure (Statistical Yearbook) of $774.51 \mathrm{mio}$.

8 The NBS data come with a breakdown into approximately 40 industries that have for the purpose of comparison here been aggregated (as meaningful) into the 16-sector classification used in the Finance Ministry and SASAC sources, and otherwise enter the residual category. 
SOEs, 67 companies ranked on the 2017 Fortune Global 500 list. Central enterprises' income tax payments in 2016 accounted for approximately one-quarter of the center's fiscal revenues (with no expenditure category indicating transfers to central enterprises). ${ }^{9}$

\begin{tabular}{|c|c|c|c|c|}
\hline & $\begin{array}{l}\text { GDP } \\
\text { (CNY } \\
\text { bn) }\end{array}$ & $\begin{array}{l}\text { Assu- } \\
\text { med } \\
\text { SOSCE } \\
\text { share }\end{array}$ & $\begin{array}{c}\text { Derived } \\
\text { SOSCE } \\
\text { value- } \\
\text { added } \\
\text { (CNY } \\
\text { bn) }\end{array}$ & $\begin{array}{c}\text { Sector } \\
\text { share in } \\
\text { SOSCE } \\
\text { value- } \\
\text { added } \\
(\%)\end{array}$ \\
\hline Gross domestic product (GDP) & \multicolumn{4}{|l|}{68,905} \\
\hline Agriculture, forestry, animal husbandry and FISHERY & 6,291 & 0.024 & 150 & 0.55 \\
\hline Mining & 1,910 & 0.417 & 797 & 2.94 \\
\hline Manufacturing & 20,242 & 0.144 & 2,921 & 10.78 \\
\hline Production and supply of electricity, heat, gas and water & 1,498 & 0.832 & 1,247 & 4.60 \\
\hline Construction & 4,663 & 0.429 & 2,000 & 7.38 \\
\hline Wholesale and retail trades & 6,619 & 0.251 & 1,659 & 6.12 \\
\hline Transport, storage and post & 3,049 & 0.540 & 1,645 & 6.07 \\
\hline Hotels and catering services & 1,215 & 0.146 & 178 & 0.66 \\
\hline Information transmission, software and information technology & 1,855 & 0.5 & 927 & 3.42 \\
\hline Financial intermediation & 5,787 & 0.9 & 5,209 & 19.22 \\
\hline Real estate & 4,170 & 0.323 & 1,348 & 4.97 \\
\hline Leasing and business services & 1,711 & 0.7 & 1,198 & 4.42 \\
\hline Scientific research and technical services & 1,348 & 0.295 & 398 & 1.47 \\
\hline Management of water conservancy, environm. and public facilities & 385 & 0.9 & 347 & 1.28 \\
\hline Service to households, repair and other services & 1,085 & 0.5 & 543 & 2.00 \\
\hline Education & 2,425 & 0.9 & 2,183 & 8.05 \\
\hline Health and social services & 1,496 & 0.9 & 1,346 & 4.97 \\
\hline Culture, sports and entertainment & 493 & 0.7 & 345 & 1.27 \\
\hline Public management, social security and social organizations & 2,662 & 1 & 2,662 & 9.82 \\
\hline Sum of sectors & 68,905 & & 27,102 & \\
\hline Share in PRC GDP (in \%) & & & 39.33 & \\
\hline \multicolumn{5}{|c|}{$\begin{array}{l}\text { GDP = gross domestic product; SOSCE = state-owned and state-controlled enterprise (category). } \\
\text { For explanations on the derivations of the assumed sector-specific SOSCE shares see Appendix } 1 . \\
\text { Sources: GDP and sector value-added data are from Statistical Yearbook 2017. Data relevant to calculating } \\
\text { the assumed sector SOSCE shares are from Statistical Yearbook 2016, and } 2017 \text {. }\end{array}$} \\
\hline
\end{tabular}

\section{State-owned Enterprise Profitability (Finance Ministry Data)}

23. The Fiscal Yearbook, issued by the Finance Ministry, provides a relatively comprehensive set of data for the years since 2006. The variables are balance sheet and profit and loss account measures, including sales revenue and main business revenue. Explicit output data such as value-added are not available. ${ }^{10}$

24. State enterprises are either central or local non-financial enterprises, with one-third of all state enterprises in 2016 being considered central, up from one-sixth in 2006 (Table 3). Central enterprises in 2016 accounted for almost half of SOE assets (a slight decline from 2006) and

9 See Schumpeter (1 March 2018), Ferrarini and Hinojales (2018), IMF (2018), Leutert (2018a), and the NBS database. Miura (2015) cites a 2009 Organisation for Economic Co-operation and Development (OECD) study which found that SOEs effectively controlled the management of $70 \%$ of the (then) 1,342 listed companies.

10 Profitability is used as a performance measure rather than some efficiency measure derived from production function estimations; value-added data or other output values are frequently not available. (Also see Appendix 2 .) 
almost two-thirds of profit (unchanged from 2009, the first year these data are available).

25 . Both the return on equity (ROE) and the return on assets (ROA) declined continuously over time, with ROE falling from $12.4 \%$ in 2006 to $4.8 \%$ in 2016 , and ROA in the same period falling from $4.4 \%$ to $1.6 \%$. Some of this decline in profitability can be traced to a relative increase in losses: the profit of profitable enterprises relative to the losses of loss-making enterprises halved, from $4.48 \%$ to $2.31 \%$.

26. The question that arises is whether the decline in profitability reflects a "real" decline in profits, or whether, for example, the introduction of the state capital budget management system (explained below) - with the new requirement to submit an increasing part of profits to SASAC or provincial ASACs_-provides incentives for enterprises to report less profit.

Table 3: Number of State Enterprises and their Performance (Finance Ministry Data)

\begin{tabular}{|c|c|c|c|c|c|c|c|c|c|c|c|c|}
\hline & $\begin{array}{l}\text { Numb } \\
\text { Total } \\
\text { (th.) }\end{array}$ & $\begin{array}{l}\text { er of en } \\
\text { Central } \\
\text { (th.) }\end{array}$ & $\begin{array}{l}\text { Local } \\
\text { (th.) }\end{array}$ & $\begin{array}{l}\text { Total } \\
\text { (CNY } \\
\text { bn) }\end{array}$ & $\begin{array}{c}\text { Assets } \\
\text { Central } \\
\text { share } \\
(\%)\end{array}$ & $\begin{array}{l}\text { Local } \\
\text { share } \\
\qquad \%)\end{array}$ & $\begin{array}{c}\text { (CNY } \\
\text { bn) }\end{array}$ & $\begin{array}{c}\text { (CNY } \\
\text { bn) }\end{array}$ & $\begin{array}{l}\text { fit } \\
\text { Central } \\
\text { share } \\
(\%)\end{array}$ & $\overline{R O E}$ & ROA & $\begin{array}{l}\text { Profit / } \\
\text { losses }\end{array}$ \\
\hline 2006 & 116 & & 6 & 27,731 & 51.7 & 53.4 & 9,801 & 1,219 & & 12.4 & 4 & 4.48 \\
\hline 2007 & 112 & & 90 & 34,707 & 54.2 & 50.1 & 14,460 & 1,744 & & 12.1 & 5.0 & 5.62 \\
\hline 2008 & 110 & 2 & 88 & 41,622 & 55.2 & 48.9 & 16,621 & 1,334 & & 8.0 & 3.2 & 3.04 \\
\hline 2009 & 111 & 2 & 86 & 51,414 & 54.3 & 49.6 & 19,872 & 1,561 & 62.3 & 7.9 & 3.0 & 3.90 \\
\hline 2010 & 114 & 26 & 87 & 64,021 & 51.6 & 48.4 & 23,417 & 2,143 & 63.4 & 9.2 & 3.3 & 4.41 \\
\hline 2011 & 136 & & 94 & 75,908 & 50.6 & 49.4 & 27,299 & 2,467 & 61.6 & 9.0 & 3.2 & 3.68 \\
\hline 2012 & 147 & 48 & 99 & 89,489 & 48.5 & 51.5 & 31,975 & 2,428 & 65.8 & 7.6 & 2.7 & 3.11 \\
\hline 2013 & 155 & 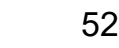 & 104 & 104,095 & 46.7 & 53.3 & 36,997 & 2,557 & 65.3 & 6.9 & 2.5 & 3.03 \\
\hline 2014 & 161 & 5 & 106 & 118,472 & 45.6 & 54.4 & 41,876 & 2,644 & 65.9 & 6.3 & 2.2 & 2.82 \\
\hline 2015 & 167 & . & 111 & 140,683 & 46.0 & 54.0 & 48,241 & 2,497 & 65.8 & 5.2 & 1.8 & 2.44 \\
\hline 2016 & 174 & 57 & 116 & 154,914 & 45.6 & 54.4 & 53,393 & 2,556 & 62.3 & 4.8 & 1.6 & 2.31 \\
\hline
\end{tabular}

ROA = return on assets; ROE = return on equity; Profit / Losses = profit of profitable enterprises divided by Notes: losses of loss-making enterprises; th. = thousand

1. The source provides enterprise numbers rounded to the thousands.

2. Central and local asset shares of 2006-2009 do not add up to total assets.

3. Profit of profitable enterprises plus losses (negative profit) of loss-making enterprises equals (total, all) profit.

4. The source does not break down profit into profit by central and local enterprises. Limited data on profit by central enterprises are available separately.

5. Additional information: In 2015, "centrally administered enterprises" accounted for $72.7 \%$ of assets in central state enterprises, and "central departmentally administered enterprises" for $27.3 \%$. For profit, the shares were $75.3 \%$ and $24.7 \%$, respectively.

Sources: Fiscal Yearbook 2016, pp. 375, 377, 378, 386f., Fiscal Yearbook 2017, pp. 366, 368, 369, $377 f$. 


\begin{tabular}{|c|c|c|c|c|c|c|c|c|}
\hline & $\begin{array}{c}\text { Number } \\
\text { of } \\
\text { enter- } \\
\text { prises }\end{array}$ & $\begin{array}{l}\text { Share } \\
\text { of all } \\
\text { enter- } \\
\text { prises }\end{array}$ & $\begin{array}{l}\text { Share } \\
\text { of } \\
\text { assets }\end{array}$ & $\begin{array}{l}\text { Share } \\
\text { of } \\
\text { equity }\end{array}$ & $\begin{array}{l}\text { Share } \\
\text { of } \\
\text { profits }\end{array}$ & $\begin{array}{l}\text { Share of } \\
\text { formal } \\
\text { employ- } \\
\text { ment }\end{array}$ & & $\mathrm{ROA}$ \\
\hline & & $(\%)$ & $(\%)$ & $(\%)$ & $(\%)$ & $(\%)$ & $(\%)$ & $(\%)$ \\
\hline National total & 167,399 & 100.0 & 100.0 & 100.0 & 100.0 & 100.0 & 5.2 & 1.8 \\
\hline 1. Agriculture & 6,954 & 4.2 & 0.8 & 0.8 & 0.1 & 7.2 & 0.9 & 0.3 \\
\hline 1.1 Farming & 3,033 & 1.8 & 0.5 & 0.5 & 0.1 & 4.7 & 1.3 & 0.4 \\
\hline 1.2 Forestry & 1,546 & 0.9 & 0.1 & 0.1 & 0.0 & 1.8 & 0.1 & 0.0 \\
\hline 1.3 Husbandry & 712 & 0.4 & 0.0 & 0.0 & 0.0 & 0.2 & 1.3 & 0.5 \\
\hline 1.4 Fishery & 321 & 0.2 & 0.0 & 0.0 & 0.0 & 0.1 & -2.9 & -1.0 \\
\hline 1.5 Implicit residual & 1,342 & 0.8 & 0.1 & 0.1 & 0.0 & 0.3 & 1.1 & 0.4 \\
\hline 2. Industry & 42,816 & 25.6 & 27.2 & 32.5 & 30.3 & 48.4 & 4.8 & 2.0 \\
\hline 2.1 Coal & 2,422 & 1.4 & 2.7 & 2.3 & -3.3 & 8.3 & -7.5 & -2.2 \\
\hline 2.2 Petroleum, petrochemicals & 771 & 0.5 & 3.2 & 7.2 & 4.4 & 5.3 & 3.2 & 2.4 \\
\hline 2.3 Metallurgical industry & 2,596 & 1.6 & 3.4 & 2.6 & -6.2 & 5.5 & -12.4 & -3.3 \\
\hline 2.4 Building materials & 2,959 & 1.8 & 0.7 & 0.7 & 0.4 & 1.7 & 2.8 & 1.0 \\
\hline 2.5 Chemical industry & 3,081 & 1.8 & 1.5 & 1.3 & 0.4 & 3.1 & 1.6 & 0.5 \\
\hline 2.6 Forest industry & 153 & 0.1 & 0.0 & 0.0 & 0.0 & 0.1 & 1.8 & 0.2 \\
\hline 2.7 Foods & 2,015 & 1.2 & 0.2 & 0.2 & 0.3 & 0.8 & 6.3 & 2.0 \\
\hline 2.8 Tobacco & 146 & 0.1 & 0.6 & 1.4 & 4.5 & 0.6 & 16.2 & 12.6 \\
\hline 2.9 Textiles & 485 & 0.3 & 0.1 & 0.1 & 0.0 & 0.5 & 1.8 & 0.6 \\
\hline 2.10 Pharmaceuticals & 864 & 0.5 & 0.3 & 0.4 & 1.0 & 0.8 & 12.3 & 7.2 \\
\hline 2.11 Machinery industry & 7,646 & 4.6 & 3.3 & 4.0 & 7.9 & 7.4 & 10.2 & 4.2 \\
\hline of which: automobiles & 1,317 & 0.8 & 1.3 & 1.9 & 6.1 & 2.5 & 16.8 & 8.3 \\
\hline 2.12 Electronics & 1,844 & 1.1 & 0.8 & 1.0 & 1.2 & 1.8 & 6.2 & 2.8 \\
\hline 2.13 Power industry & 7,126 & 4.3 & 6.9 & 6.9 & 14.5 & 5.8 & 10.9 & 3.7 \\
\hline 2.14 Municipal public goods/utilities & 5,525 & 3.3 & 1.6 & 1.9 & 1.5 & 2.4 & 4.2 & 1.7 \\
\hline 2.15 Other industry & 5,183 & 3.1 & 1.9 & 2.4 & 3.5 & 4.4 & 7.6 & 3.3 \\
\hline 3. Construction & 10,343 & 6.2 & 7.1 & 6.1 & 6.6 & 7.4 & 5.6 & 1.6 \\
\hline 4. Geological prosp., water conserve. & 1,714 & 1.0 & 0.6 & 0.9 & 0.1 & 0.4 & 0.6 & 0.4 \\
\hline 5. Transport and storage & 17,152 & 10.2 & 13.4 & 14.1 & 6.9 & 13.4 & 2.5 & 0.9 \\
\hline 5.1 Railway transport & 1,317 & 0.8 & 4.6 & 4.8 & 0.4 & 5.4 & 0.5 & 0.2 \\
\hline 5.2 Road transport & 4,300 & 2.6 & 4.9 & 5.1 & 1.1 & 5.1 & 1.1 & 0.4 \\
\hline 5.3 Water transport & 1,580 & 0.9 & 0.8 & 1.1 & 1.4 & 0.6 & 6.5 & 3.1 \\
\hline 5.4 Air transport & 632 & 0.4 & 0.9 & 1.1 & 1.5 & 0.9 & 6.6 & 3.1 \\
\hline 5.5 Storage & 7,224 & 4.3 & 1.6 & 0.6 & 0.5 & 0.9 & 3.8 & 0.5 \\
\hline 5.6 Implicit residual & 2,099 & 1.3 & 0.8 & 1.3 & 2.0 & 0.7 & 7.9 & 4.7 \\
\hline 6. Post and telecommunications & 1,428 & 0.9 & 2.6 & 4.5 & 7.4 & 4.6 & 8.5 & 5.2 \\
\hline 7. Trade and catering & 25,317 & 15.1 & 4.7 & 4.1 & 12.0 & 5.9 & 15.2 & 4.6 \\
\hline 8. Real estate & 16,152 & 9.6 & 9.9 & 8.0 & 8.7 & 2.2 & 5.6 & 1.6 \\
\hline 9. Information technology services & 2,008 & 1.2 & 0.3 & 0.3 & 0.8 & 0.6 & 12.3 & 5.3 \\
\hline 10. Social services & 26,232 & 15.7 & 16.8 & 23.2 & 11.8 & 5.5 & 2.6 & 1.2 \\
\hline 11. Health, sports, welfare & 800 & 0.5 & 0.1 & 0.1 & 0.0 & 0.3 & 1.4 & 0.6 \\
\hline 12. Education, culture, broadcasting & 6,139 & 3.7 & 0.5 & 1.0 & 1.4 & 1.2 & 7.4 & 4.5 \\
\hline $\begin{array}{l}\text { 13. Scientific research, techn. services } \\
\text { 14. (Administrative) organs, mass }\end{array}$ & 8,111 & 4.8 & 1.0 & 1.2 & 2.5 & 2.0 & 11.3 & 4.5 \\
\hline organizations, and others & 2,233 & 1.3 & 15.1 & 3.2 & 11.2 & 1.1 & 18.5 & 1.3 \\
\hline
\end{tabular}


27. Table 4 presents some of the limited industry (economic sector) data available from the Finance Ministry (in greatest possible industry detail), for 2015. Approximately one-quarter of state enterprises are located in "industry" (mining, manufacturing, utilities), accounting for onequarter of state assets, one-third of state equity and profit, and for almost half of SOE employment. ROE and ROA differ drastically across industries. For example, the metallurgical industry has an ROE of $-12.4 \%$, while the tobacco industry has an ROE of $16.2 \%$. The highest ROE is found in "Administrative organs, mass organizations, and others," at $18.5 \%$ (although the ROA is at best mediocre).

\section{STATE-OWNED ENTERPRISE REFORMS}

28. By the early 1990s, the decline in state-owned enterprise (SOE) profitability had become a matter of concern. Attempts at sector-specific SOE reforms did not yield the desired success and by 1997 it had become clear that more SOE reforms were needed. Profitability was the driving factor. In March 1998 at the National People's Congress, incoming Premier Zhu Rongji in discussing SOE reform, announced "there is no more money" (meiyou qian).

29. Reforming SOEs took many forms, not least of which was laying off vast numbers of workers. But in the long run, a complete restructuring was pursued of how state ownership of means of production is organized. The establishment of the State(-owned) Asset Supervision and Administration Commission (SASAC) and its provincial counterparts (provincial ASACs) followed in 2003. While this reorganization solved some SOE problems, it could not resolve all governance issues.

30. By the late 2000s, the role of SOEs in the economy had changed. While a very few economic sectors (such as the petroleum industry, tobacco, the telecommunications industry, and banking) remained confined to state ownership, most economic sectors had no ownership restrictions. At the same time, economic policies of transition and reform gave way to industrial policies irrespective of state or private ownership form (but with a distinction between domestic vs. foreign ownership).

31. In the 2010s, SOE reform became more a matter of tying up loose ends rather than initiating major new reform measures, and even that was a haltingly implemented undertaking. Apart from (Chinese Communist) "Party building" in SOEs, three elements of SOE reform rose to prominence: mixed ownership reform, a new state capital management system, and continued implementation of the 'modern enterprise system.'

\section{A. State-owned Enterprise Reform Program of 1998-2000}

32. The First Plenum of the $15^{\text {th }}$ Chinese Communist Party Central Committee (CCPCC) at its meeting on 19 September 1997 initiated a three-year SOE reform program (1998-2000) which laid the foundation for state ownership in the PRC today. Two slogans summarized the reform program (SETC, 28 November 1997).

33. The first slogan was "seize the big ones and let go of the small ones" (zhuada fangxiao). For large and medium(-sized) SOEs, i.e., the "big ones," the reform program had two major objectives: most large and medium-sized SOEs were to adopt the modern enterprise system, and most lossmaking large and medium-sized SOEs were to "escape their difficulties" (tuokun). Small SOEs, mostly owned by local governments, were to be "enlivened" (gaohuo) by any means necessary 
to improve their finances. ${ }^{11}$

34. The modern enterprise system encompasses four elements:

- clearly allocated property rights,

- clear rights and responsibilities,

- separation of government and enterprise, and

- scientific management.

Key to the establishment of the modern enterprise system is the gradual switch to the company system, in accordance with the Company Law passed in December 1993 (NPC, 29 December 1993, since amended three times, in 1999, 2004, and 2013). The Company Law established a regulatory framework for limited liability companies - with the sub-category of solely state-owned limited liability companies-and stock companies. (But, as further discussed below, while corporatization may achieve the first goal of clearly allocating property rights, it is less effective in clearly allocating rights and responsibilities, and perhaps least effective in separating government and enterprises.) Adoption of the modern enterprise system is nearing completion only today.

35. The second slogan was "three reforms and one enhancement" (san gai yi jiaqiang):

- reducing employment in SOEs while trying to create re-employment opportunities,

- increasing SOE equity relative to debt,

- letting some SOEs go bankrupt or merging them with other enterprises,

- and enhancing enterprise management.

These reforms required supporting measures. The three-year SOE reform program was accompanied by a complete overhaul of the social security system. Traditionally, all social security tasks were concentrated within an SOE. These tasks were now shifted to external institutions for SOE reform, including enterprise bankruptcy, to proceed unencumbered. ${ }^{12}$ A provincial-level pension system was established in 1997, a new urban medical insurance system in 1998, and a municipal-level unemployment insurance system in 1999.

36. One effect of economic reforms was the increasing indebtedness of SOEs as the state budget no longer provided investment funds and working capital and firms were directed to banks for loans. By the mid-1990s, industrial SOEs' average liability-asset ratio, or "debt-asset ratio," had reached about $65 \%$. The government resorted to debt-equity swaps and established resolution trust companies to reduce the debt burden of viable SOEs. A debt-equity swap of CNY 460bnequal to approximately $5 \%$ of total SOE industrial assets in 2000-was announced in 2000 for 601 predominantly large, centrally owned industrial SOEs (but most likely only implemented in 2001 and 2002). In addition, each of the four big state commercial banks in the PRC set up an

11 Reform of small SOEs _ predominantly owned by local governments and in 1997 accounting for barely $15 \%$ of industrial SOE value-added — was left to local governments. Governments across the PRC began to experiment with a host of reform measures for small industrial SOEs. These included the sale of small SOEs to their employees (adoption of the "stock cooperative" system), the merger of two or more SOEs, the take-over of one or more small SOEs by a larger SOE, the transfer of profitable production processes into new SOEs while letting the old ones go bankrupt, the leasing of complete SOEs or some of their assets, privatization, the creation of joint ventures with foreign enterprises, and bankruptcy.

12 Average annual employment in industrial SOEs by one account halved from 40.40mio in 1997 to $20.96 \mathrm{mio}$ in 2000. Employment in all SOEs fell by 25.5m between 1998 and 2001 (SC, April 2002, p. 41). The safety net for dismissed workers began with "re-employment service centers" (three years), followed by unemployment insurance (two years) and eventually a "basic living allowance." 
asset management company to in 2000 take over CNY 930bn of bad loans from the four banks. ${ }^{13}$

37. At the time of the SOE reform program, the PRC did not have a uniform enterprise bankruptcy law (which only came into effect in June 2007). The State Council in 1997 established a "national leading group for SOE mergers and bankruptcies and staff and worker re-employment" to formulate annual bankruptcy plans for SOEs that would be socially and financially feasible. The national leading group between 1997 and 2000 approved (or planned) the merger or bankruptcy of 5,335 industrial SOEs, which required writing off CNY 208.64bn in bank loans (principal and interest due). By 2000, of the 6,599 large and medium-sized loss-making industrial SOEs in 1997, 1,415 had merged, had entered bankruptcy proceedings, or were closed. ${ }^{14}$ Mergers were clearly the favored procedure, while planned/policy bankruptcies continued well into the 2000s (and "last" bankruptcies were still under discussion in the mid-2010s).

38. Enhancing enterprise management falls under the larger heading of improving corporate governance (how to ensure that managers of the firm act in the interests of the owners, or, in a larger context, the stakeholders). While privatization may be viewed as a simple method to align the interests of enterprise managers with those of the owners, privatization of SOEs in the PRC was pursued only for small SOEs and heavily restricted for larger SOEs.

39. The 1998-2000 SOE reform program ended the "iron rice bowl" of guaranteed lifelong employment in SOEs. After almost fifty years, the concept of SOEs as one's "work unit" (danwei) which ruled all aspects of life from schooling to housing, health care and pensions dissolved within just three years. The introduction of the company system - modeled on Western company lawsand the introduction of a society-wide social security system were to profoundly change how SOEs are managed. SOEs were to be separate from the state and to be run as modern companies. But by 2003 it had become apparent that some form of institutional oversight over SOEs was still needed.

\section{B. State Asset Supervision and Administration Commission, From 2003 Onward}

40. Hand in hand with the SOE reform program of 1998-2000, a major administrative restructuring cut the central government's staff by half and abolished most line ministries, with some of their functions shifted to departments of the State/National Development and Reform Commission (NDRC, the successor to the State Planning Commission) and the State Economic and Trade Commission (merged into the Ministry of Commerce in 2003). In 2003, the State(owned) Asset Supervision and Administration Commission (SASAC) was established to, on behalf of the State Council, supervise and administer centrally owned (non-financial) SOEs. Corresponding provincial ASACs were set up shortly thereafter, not only replicating the new administrative structure at the center, but through the explicit existence of central SASAC vs. local ASACs also clearly subordinating SOEs either to the center or a locality.

41. By the end of 2003, SASAC was in charge of 196 (non-financial) conglomerates, i.e., large holding companies that themselves owned multiple subsidiaries. Industrial conglomerates dominate the list of SASAC's SOEs-with 34,280 state-owned and state-controlled industrial enterprises alone (Industry Statistical Yearbook 2003, p. 54) —but the list also includes the three

${ }^{13}$ For comparison, total loans by all financial institutions in the PRC (at the time, predominantly loans extended by the four banks) at end-2001 amounted to CNY 11.2trn (Statistical Yearbook 2003, p. 704). The four asset management companies each received CNY 10bn in start-up capital from the government and were otherwise financed by bonds guaranteed by the Finance Ministry, as well as an unknown volume of refinancing from the People's Bank of China. The objective was to dispose of the bad loans within a ten-year framework, which was largely achieved, albeit at a low recovery rate (precise data are unavailable, various sources suggest a recovery rate of $10-25 \%$ ).

14 See China Infobank (25 June 2001) and Fiscal Yearbook 2001, p. 109. 
major airlines and the three telecommunications firms. In 2005, SASAC organized 21 sectoral restructuring programs as well as a "final" round of policy-related bankruptcies of large enterprises. By late 2018, the number of SASAC conglomerates had shrunk to 97 , mostly through mergers (with 124,966 individual enterprises in 2015 (Table 1)). ${ }^{15}$

42. SASAC played an important role in three subsequent SOE-related reforms. ${ }^{16}$ The first was management buyouts (MBOs) at small and medium-sized SOEs in the mid-2000s. A rise in MBO activity in 2004 triggered concerns about "insider privatization" and "asset stripping" and led to investigative teams being dispatched and MBO activity being slowed down; MBOs of large SOEs were blocked. By 14 April 2005, SASAC issued comprehensive regulations on MBOs at small and medium-sized SOEs, establishing types and conditions of transactions, requiring transactions to be conducted in transparent fashion on provincial property rights markets, and setting principles for the calculation of minimum prices. This means that SASAC regularized what de facto was a rather unregulated privatization of small and medium-sized SOEs, primarily affecting locally owned SOEs. Apart from MBOs at small and medium-sized SOEs in the mid-2000s, full-scale privatization has never been an option. Listing on the stock market, however, became a major venue for attracting private capital.

43. A second SOE-related reform was the transformation of originally non-tradable state shares of listed SOEs into tradable shares. In 2001, the China Securities Regulatory Commission (CSRC) implemented a sell-off of state shares that triggered a massive market decline and was subsequently stopped. In 2005 , SASAC supported a second attempt by the CSRC to transform non-tradable state shares into tradable shares. This second round was conducted on a companyby-company basis (requiring approval by a two-thirds majority of public shareholders) and typically involved giving private shareholders 3 bonus shares for every 10 tradable shares they held, while government holders of non-tradable shares had to agree to sell no more than a small proportion of their shares during a 3-year lockup period. SASAC's role in the transformation was that of the owner of SOEs, pursuing the smallest possible dilution of the value of state holdings.

44. The third reform was the introduction of the state capital management budget (guoyou ziben jingying yusuan) in 2007. For the first time since a 1994 tax reform, SOEs were again being asked to surrender profit-albeit only a small share thereof. (SOEs have since 1994 paid corporate income taxes and continue to do so.) In 2007, SASAC enterprises were newly subjected to three levels of profit remittances: 17 firms plus the State Tobacco Monopoly faced a 10\% profit remittance rate; 99 firms a 5\% rate; 32 firms were exempted from any profit remittance for three years (mostly military industrial firms and research institutes); and the grain and the cotton reserve companies were permanently exempted. Local ASACs proceeded similarly for their enterprises. The new charge on profits was accompanied (and partly offset) by a lowering of the corporate income tax rate from $33 \%$ to $25 \%$ on 1 January 2008 (increasing residual profits), but also by the elimination of some previously enjoyed tax breaks (reducing profits).

45. The profit remittance rates were subsequently adjusted at least twice (first time in 2011). By 2014 , the State Tobacco Monopoly paid a $25 \%$ profit remittance rate, most big SOEs $15 \%$ or $20 \%$, and all others at least $10 \%$ (with 2 firms, presumably still the grain and the cotton reserve companies, being exempted). The profit is remitted to the Finance Ministry in the first instance, which then redistributes the funds to SASAC. SASAC's primary use of these funds has been for capital outlays, restructuring, and general "reform costs," i.e., the remittances likely are being used to cover the losses and restructuring costs of SOEs. The profit remittance rate is expected to rise to $30 \%$.

\footnotetext{
15 For the most up-to-date list of SASAC conglomerates, see the SASAC homepage (www.sasac.gov.cn).

16 This and the following two paragraphs draw on Naughton $(2005,2008)$.
} 


\section{Disparate Strands of State-owned Enterprise Policy in the 2010s}

46. By the late 2000s, SOE reforms were deemed to have been broadly completed. Policy makers' attention shifted to industrial policy as a tool to maintain the economic growth momentum. Industrial policy made little distinction between SOEs and non-SOEs. The new Party leadership that came to power in 2012 then considered further, minor SOE reform measures but without decisive advances. By 2018, Party Secretary Xi Jinping repeatedly issued a renewed commitment to significant state ownership. All along, a key concern for the new leadership was strengthening Party control over SOEs.

\section{Industrial policy}

47. In 2010, the State Council identified seven "strategic emerging industries" which were to be supported in the following years, with a target share in gross domestic product (GDP) for 2015 of $8 \%$, and for 2020 of $15 \%$. The seven industries are:

- energy saving and environmental protection technologies,

- next generation information technology,

- biotechnology,

- high-end equipment manufacturing,

- new energy,

- new materials, and

- $\quad$ new energy vehicles. ${ }^{17}$

While industrial policy historically refers to SOEs, this policy document explicitly encouraged nonstate (minjian) investment.

48. The emerging industries policy was followed in 2015 by a State Council declaration on "Made in China 2025," the PRC version of Germany's 2012 "Industry 4.0" (fourth industrial revolution). ${ }^{18}$ Breakthroughs are to occur in ten priority industries: information technology, numerical control tools and robotics, aerospace equipment, ocean engineering equipment and high-tech ships, railway equipment, energy saving and new energy vehicles, power equipment, new materials, medicines and medical devices, and agricultural machinery. State vs. private ownership is not an issue; "domestic vs. foreign" ownership is.

49. "Made in China 2025" implies that the PRC government subsidizes domestic products while excluding foreign alternatives; it sets substitution targets for foreign products; it provides financial resources for various research and development funds that benefit domestic enterprises; it requests the transfer of foreign technology in exchange for domestic market access; it restricts access to public procurement for foreign firms and limits the possibility for inbound foreign direct investment; it controls crucial technologies such as encryption devices and codes, and through its Cyber Security Law of 2016 ensures easy access for the state (and thereby possibly its enterprises) to the data of international companies operating in the PRC. ${ }^{19}$ The ownership structures are often hidden, with seemingly private enterprises (especially those investing abroad)

17 For an English language summary of the State Council document see The US-China Business Council (2013).

18 The four revolutions are: water- and steam-powered mechanical manufacturing, mass production based on electric power, automation of manufacturing based on information technology, and cyber-physical systems (smart factories with embedded information technology systems).

19 See, for example, Wuebbeke et al. (2016). 
ultimately under state control. ${ }^{20}$

50. In June 2018, censors informed all state media agencies to avoid mentioning "Made in China 2025" in their reports. This followed concerns in the United States (U.S.) and in Europe about the acquisition of technology by PRC firms, business concerns that the program would discriminate against foreign firms in the PRC, and U.S. President Trump's explicit criticism of PRC industrial policy. Subsequently, mentioning of the program on the Ministry of Commerce website dropped drastically and PRC sources claimed that "Made in China 2025" involved no personnel, budget, or resource allocations and was simply a visionary document. Other sources report that in the chosen pilot cities for "Made in China 2025," earlier regional development plans were being translated into "Made in China 2025" terms and funds were being disbursed rather indiscriminately, including for projects that do not necessarily have much relation to the center's industrial policy intentions. $^{21}$

51. Another industrial policy initiative is the "supply-side structural reform" agenda first introduced by the Finance and Economics Leading Small Group of the Party Central Committee in November $2015,{ }^{22}$ primarily intended to curb excess capacity, independent of ownership form. The agenda's five elements are: eliminating excess capacity, especially in steel and coal production; reducing stocks, mostly in real estate in second- and third-tier cities; de-leveraging across the economy; lowering costs, including those due to taxes, regulations, and social security contributions; and a broad catch-all call for "strengthening weak points."

52. The agenda applies independent of ownership form. But with SOEs accounting for between half and three-quarters of total assets by above-norm industrial enterprises in three relevant industries (coal mining, ferrous metals mining and dressing, and the ferrous metals smelting and rolling processing industry), SOEs are a prime target of the supply-side structural reform agenda. The agenda provides a nod to publicly owned firms to merge and become more efficient (i.e., it tasks SASAC with resolving a particular problem among its enterprises). It also encourages local officials to implement environmental and other regulations and to eliminate the least desirable production capacities, independent of ownership form. ${ }^{23}$ To the extent that the reach of central authority into central institutions (SASAC and its SOEs) is stronger than into provinces, the supply-side structural reform agenda affects primarily large, central SOEs. Since oversupply means low profitability, the supply-side structural reform agenda can also be viewed as a program to address poor SOE performance in certain sectors.

\section{State-owned enterprise reforms since the Third Plenum of 2013}

53. The Third Plenum of the $18^{\text {th }}$ Chinese Communist Party Central Committee (CCPCC) on 12 November 2013 issued a lengthy decision on major issues in deepening reform that included paragraphs elaborating on SOE reforms (CCPCC, 12 November 2013). The decision followed the

20 Private entrepreneur Li Shufu (of car manufacturer Geely) insists when questioned by German media about his newly acquired stake in German car maker Daimler that he is a private entrepreneur with no ties to the PRC authorities. In PRC state media he is reported as saying that the purchase of the stake in Daimler was to "support the growth of the Chinese auto industry" and to "serve our national strategies." The purchase of the stake in Daimler must have been approved (if not ordered) by the PRC's top leadership. (See Wuebbekke et al, 2016, and Chazan, 13 March 2018)

21 See, for example, Leng and Zheng (26 June 2018) and Wang (10 July 2018).

22 Articles by an "authoritative personage" in Renmin ribao (People's Daily) on 4 January 2016 and on 9 May 2016 widely promoted the supply-side structural reform agenda. Naughton $(2016 a, b)$ elaborates on the supply-side structural reform agenda.

23 The agenda promotes particular actions rather than commands closures, leaving much flexibility in implementation. It came at a time of declining profitability and increasing losses due to plummeting prices for coal and steel, and promotes market-conforming behavior while maintaining a legal framework that applies to all firms. 
standard pattern of long sentences of what is to be "promoted" or "strengthened," etc., with each sentence consisting of a list of half a dozen or more items. Three themes stand out in this Third Plenum decision: the development of a mixed ownership economy, improvements to the stateowned asset management system, and full-scale adoption of the modern enterprise system. These three themes have dominated the SOE reform discussion since, and have led to numerous experiments and further developments.

54. The Third Plenum decision was followed by "guiding opinions for deepening SOE reform" issued by the CCPCC in conjunction with the State Council two years later (CCPCC 24 August 2015). The Guiding Opinions reiterated the earlier statements, elaborated on SOE reform in hundreds of declarations of what was to be done, and set a deadline of 2020 to establish the state-owned asset management system, the modern enterprise system, and the market-oriented "operation mechanisms." ${ }^{24}$ Key items listed include the following: to complete the reform of SOEs, make progress on developing the mixed economy, improve the corporate governance structure, improve state-owned asset supervision, improve the allocative efficiency of state capital, and strengthen Party building in enterprises. SOEs are to be relieved of "social functions" and "problems of history." SOEs are to be divided into commercial businesses (whose focus is to be performance, value preservation and increase, and market competitiveness) and public welfare enterprises. ${ }^{25}$ In the case of commercial SOEs, those in national security and in "lifeline" businesses must be state-controlled. By $2020,30 \%$ of state-owned capital gains are to be turned over to the Finance Ministry for "people's livelihood" purposes.

55. The fact that it took two years to issue Guiding Opinions reflects difficulty in reaching an understanding on what to do about SOEs. Naughton (2016b) reports of 34 SOE-related initiatives in early 2014, proposed by various government organizations-from SASAC to the Ministry of Finance, the National Development and Reform Commission (NDRC), and the Ministry of Labortypically with differing views of how to proceed.

56.In the end, much decision-making power was concentrated in Party leading groups. Thus, already in 2013, Party Secretary Xi Jinping created a Central Leading Group for Comprehensively Deepening Reform, chaired by himself, with a specialized subgroup for Economic System and Ecological Civilization System Reform. The de facto headquarters of the latter was the staff office of the Central Leading Group on Financial and Economic Affairs (headed by Liu He, key economic advisor to Xi Jinping). This staff office then became the highest authority for developing SOE reform measures, largely bypassing the NDRC and SASAC (Leutert 2018a). Consequently, the Guiding Opinions were issued by the CCPCC (in conjunction with the State Council). But because a Party leading group was handling SOE reform, the Guiding Opinions remained vague and lacked the support of the bureaucracy that would be needed for implementation and experimentation.

57. From 2015 to late 2018, numerous distinct reform measures have been issued by the State Council, SASAC, Ministry of Finance, and other central organs, most recently at the rate of about three per month. These tend to be "opinions,' "interim measures," "views," and "guidance" rather than major reform documents. Together, they amount to " $1+\mathrm{N}$ " SOE reform strategy documents: the Guiding Opinions and an a priori undetermined number of policy documents of various

${ }^{24}$ An introductory paragraph reads "The reform of state-owned enterprises must follow the rules of the market economy and the business development law, adhere to the separation of government functions from enterprise management, the separation of government's public affairs management function from its state-owned asset management function, and the separation of ownership from the right of management [etc.]."

25 SASAC (30 December 2015) elaborates on this binary distinction. The finance sector and "culture" are explicitly subjected to "other regulations." 
degrees of specificity. ${ }^{26}$

58. The first of the three SOE reform themes, mixed ownership reform, has two aspects: (i) Investment by the non-state economy in the state economy and vice versa, and (ii) employee share ownership. On both dimensions, developments are slow, especially on employee share ownership where developments seem to not have progressed beyond experimentation.

59. The Guiding Opinions of 2015 suggest the introduction of mixed ownership conducive to transformation and upgrading particularly in the fields of petroleum, natural gas, electricity, railway, telecommunications, resource development and public utilities, though this list appears flexible across different official documents. Investment by the non-state economy in SOEs so far has mostly been interpreted as the result of government arm-twisting, such as when the government "successfully pressured Baidu, Tencent, Alibaba, and JD.com to invest in a restructuring of stateowned telecom operator China Unicom" (Wang and Xie, 2018).

60. Beyond equity ownership, the mixed-ownership concept also includes various forms of cooperation, such as "military-civil fusion" (junmin ronghe) introduced by Xi Jinping in 2015, with inefficiency in the military sector triggering a call for private enterprises to collaborate with the military while opening military research facilities for civilian use. ${ }^{27}$ Another aspect of mixed ownership is public-private partnerships (PPPs). The NDRC maintains a webpage with a list of current projects; ${ }^{28}$ the take-up seems low, with only a handful of projects in each province. Miura (2015, p. 22) reports on local experiments and concludes from specific evidence on power transmission and distribution pilot projects in Inner Mongolia, in which another aspect is the intended separation of power production and distribution, that "the government is more interested in the use of PPPs to expand investment than in the separation of network maintenance and operations, indicating the reform process is tending to flow along the line of least resistance."

61. The second of the three SOE reform themes, establishment of a state-owned asset management system, concerns the reorganization of large state-owned holding companies into (or the creation of) formal state-owned capital management companies, which would allow the government to, as investor, focus solely on supervision. The result is little different from the current structure of "SASAC - state-owned holding companies (or very large SOEs) - individual SOEs or companies," except that the state-owned holding companies (or newly "state-owned capital management companies") gain more formal authority with clearly assigned tasks. Thus, some such state-owned capital management companies might function along the lines of Singapore's Temasek Holdings (a government financial investment company) with maximizing shareholder returns as sole objective. Other state-owned capital management companies may have different

${ }^{26}$ Citi (2018) provides an overview of recent documents. The issues range widely and include the following: experiments with employment stock ownership plans in financial institutions (though development and policy banks are to remain fully state-owned, and the state continues to hold a controlling share in large and influential financial institutions); improved supervision of listed SOEs and of transactions involving state-owned assets; improvements to corporate governance; CNY 500bn will be used for debt-equity swaps, advancing mixed ownership forms, and facilitating deleveraging; further reorganization of central SOEs and further reforms in the oil and gas industry; clarification of the function and classification of SOEs; and removal of social functions and historical burdens.

27 This is a particularly sensitive topic for private technology firms that sell internationally and may be sanctioned abroad for collaborating with the PRC military. Thus, U.S. security agencies warn telecommunication firms against using equipment from Huawei, while Australia banned Huawei and ZTE from providing $5 \mathrm{G}$ technology to mobile phone networks in Australia (Bond, 24 October 2018).

28 See http://tzs.ndrc.gov.cn/zttp/PPPxmk/xmkl, accessed 7 October 2018. 
objectives, especially those providing public goods. ${ }^{29}$

62. The reduction in the number of SASAC companies from the current 97 to approximately 30 50 by 2020-2022 appears to be moving along similar lines if the remaining companies are then reshaped into state-owned capital management companies. But a key issue is the missing progress in the classification of existing SOEs by function, which would then allow functionspecific policies, from profit maximization to "safeguarding" a national interest or the provision of public goods. ${ }^{30}$

63. The third of the three SOE reform themes, establishment of the modern enterprise system, is in part a continuation of a theme reaching back to the 1998-2000 SOE reform program. The last SOEs that have not yet become formal companies are to do so, thus subjecting all SOEs to the Company Law. But "modern enterprise system" also refers to corporate governance, including management assessment criteria, and a discussion of in what sectors state-owned capital should be concentrated. This has led to a variety of reform measures. For example, individual ministries and government departments have decided to relax ownership restrictions in sectors under their administration; private enterprises have begun to enter the fringes of the mobile telecommunications market, while the three national airlines (Air China, China Eastern, and China Southern) face increasing competition from new low-cost carriers that are no longer limited to provincial state-owned airlines.

64. A multitude of other SOE reform measures that do not necessarily fit one of these bigger themes exist. For example, SASAC has required central SOEs to reduce their average assetliability ratio by 2 percentage points by 2020 , a measure that is being viewed as rather difficult to achieve. $^{31}$

\section{Role of the Chinese Communist Party}

65. The role of the Party in SOE reform was one of the key tenets of the 2015 Guiding Opinions as well as the exclusive topic of a separate document ("Various Opinions"), issued almost simultaneously in 2015 (CCPCC, September 2015). The key phrase on the role of the Party is to "give full play to the political core role (zhengzhi hexin zuoyong) of the Party organization in SOEs," or, in a variation, "to give full play to the core role of the party leadership and the core role of the party committee." The political core role of the Party organization in SOEs is a commonplace historical theme that has become more strident in recent years. ${ }^{32}$

66. An article authored by the SASAC Party committee and published in Qiushi, a Party journal, on 31 May 2016 cites Party Secretary Xi Jinping as emphasizing "Strengthening the Party is most fundamental to unswervingly make SOEs stronger, better, and bigger," and "The priority in SOE reform is to adhere to Party leadership, otherwise it is not socialism with Chinese characteristics." The article goes on to say that the Party's leadership must not be outside the corporate governance structure. Instead: "We must guarantee and implement that the Party has the

29 Miura (2015) reports on extensive pilot programs in Shanghai which resulted in the creation (or re-labelling) of two state-owned capital investment companies, one in charge of financial institutions, and the other in charge of numerous non-financial companies.

30 Miura (2015: 14) reports that SASAC has issued four requirements for companies to be restructured into stateowned capital investment companies: (i) net sales of CNY10 billion-CNY50 billion; (ii) most of the subsidiaries must be listed companies; (iii) ample liquid capital; and (iv) must be a conglomerate.

31 SASAC announced the measure in January 2018 . The current ratio is $66 \%$, compared to $54 \%$ in 2011 . For details, see IMF (2018, p. 56) and Gatley (2018).

32 See, for example, CCPCC, 31 October 2004, and in an accompaniment to the Third Plenum decision of 2013, in CCPCC Organization Department and SASAC Party Committee (2013). 
following rights: to play the leading role in enterprise reform, to participate in major decisions, to play the leading role in the selection of important management cadres, to supervise the professional behavior of party members and cadres, to maintain the legitimate rights and interests of the workers, and to lead the ideological and political work and corporate culture."

67. In assessing the economic performance of an SOE, the SASAC supervision department is to equally consider the Party building work. The requirements of Party building work are to be included in the 'charter' of SOEs. The Party is in charge of cadre administration (dang guan ganbu), i.e., the Party is in charge of selecting and appointing key SOE personnel. Major SOE decisions must first be passed by the Party committee for suggestions. Party personnel in SOEs are to have the same rank and compensation as the management team. The expenses of Party work are born by the SOE.

68. Later in 2016, the Xinhua News Agency cited Party Secretary Xi Jinping as stressing that by strengthening and improving Party leadership in SOEs, "SOEs become the Party, SOEs become the state's most reliable pillar, SOEs become a major force in resolutely implementing Central Committee decisions and instructions, [...,], a major force in implementing the important strategies of 'Going Out' and of 'One Belt One Road' [...]." Xi Jinping continued with "Make SOEs strong, excellent, and big" (zuo qiang zuo you zuo da), "Ensure that the Party organ's leadership and control over the selection and employment of SOE personnel will not change," and "The Party's leadership over SOEs is an organic and unified political, ideological, and organizational leadership." 33

69. Xi Jinping's emphasis on SOEs continues well into 2018. On 29 September 2018, Xi Jinping was reported as stating during a visit to an SOE: "Our SOEs should continue to become stronger, better and larger. [...] All statements and arguments saying we don't need SOEs any more or we should diminish SOEs are wrong and one-sided. [...] Any thoughts or comments that doubt or bad-mouth SOEs are wrong" (Gan, 2018).

70. Party influence in SOEs is not limited to matters such as participating in major decisions. As the 2015 Guiding Opinions state, "there should be some overlap between the management personnel and party leadership, chairman and general manager should be different people in principle, and the party secretary and chairman are usually the same person." Leutert (2018a) confirms in an examination of core central SOEs that in more than $90 \%$ of these core central SOEs, the Party secretary simultaneously serves as chairman of the board of directors. It is often the case that deputy Party secretaries serve as managers and as chair and deputy chairs of the supervisory board, i.e., all decision-making as well as controlling and supervisory authority is concentrated in the SOE's Party committee. Supervisory authority is also explicitly assigned (in the 2015 Guiding Opinions) not only to the Party committee but also to the (national) Party Disciplinary Commission cell that is attached to the Party committee.

71. A relatively comprehensive example from the finance sector may illustrate the degree to which the formal mechanisms of corporate governance enshrined in the Company Law are supplemented by Party arrangements. The China Construction Bank, which is listed on the stock market, has a manager (chief executive officer [CEO]), a board of directors, and a supervisory board as stipulated in the company law for stock companies. It also has a Party cell. The manager (CEO) is the deputy Party secretary of the Party cell, and the three deputy managers are members of the Party cell (as are the internal auditor and the two assistants to the manager). The chair of the Board of Directors is the Party Secretary. The chair of the Supervisory Board is a second

33 The Party's leadership role in SOEs (and its role in implementing Party policies in the non-public economy) is also enshrined in the Party Constitution (http://www.12371.cn/special/zggcdzc/zggcdzcqw/, accessed 8 October 2018). 
deputy Party Secretary. ${ }^{34}$ The bank's Party cell is embedded in the larger Party organization, to which it reports and from which it receives instructions.

72. The dominance of the Party within SOEs is in stark contrast to the policies of the 1980s and early 1990s to separate Party from government, and government from enterprises. While separation of government and enterprises is still on the agenda, the Party now directly controls the enterprises (and increasingly bypasses government via the assumption of government functions in Party leading groups). ${ }^{35}$

73. The decision to formalize Party building by explicitly mentioning it in SOEs' corporate charters has already borne fruit. As of early 2018, at least 30 SOEs listed in Hong Kong have changed their charters to give the Party a formal role in their governance. ${ }^{36}$ The dominance of the Party is also widely recognized in the press. Thus, Mitchell (24 October 2018a) in discussing the appointment of Sinochem Chairman Fank Ning Gaoning as simultaneous head of ChemChina (a competing group) without any reference to a potential merger between these two Global 500 groups, writes: "The only stakeholder that matters in Chinese SOEs is the Communist party. Its opaque prerogatives trump everyone else's."

74. The escalation of the U.S. trade war with the PRC in 2018 will likely only have strengthened the importance of SOEs to the PRC leadership and the importance of Party control over SOEs. When the U.S. is technologically in a position to at a moment's notice destroy very large PRC firms-such as ZTE when the U.S. refused to supply the chips around which ZTE's cell phones are built until a compromise was found-it is in the PRC leadership's eminent interest to protect what it will view as a danger to national security and social stability, and establish a complete domestic industrial structure. The size of investments needed in, for example, the semiconductor industry and the (long) time horizon and the importance for the national economy will all favor to place such production under direct Party control, in state ownership, a tendency that will likely only become more pervasive with the U.S. trade war.

75. The Party is also increasingly embedded in private companies. ${ }^{37}$ All companies in the PRC must have a Party committee. Many private companies share operations with the state; for example, the technology companies Baidu, Alibaba, and Tencent have joint labs for research and development with state entities. Financing flows flexibly between the state and the private sector, such as when Xiaomi's initial public offering is supported by state-owned entities as six of the seven anchor investors. The government protects domestic private enterprises against foreign competition, such as in the technology sector with the Great Firewall. Private enterprises, seemingly independent, cannot function without close co-operation with the government and thereby Party.

34 This particular bank example is chosen due to the details provided for this one case in the magazine Caijing, no. 131, 18 April 2005.

35 The traditional "the Party administers the cadres" (dang guan ganbu), has, as McNally (2002) writes, become a "the Party administers everything" (dang guan yiqie). And as Leutert (2018a) points out, as of March 2018 the (Party) Central Leading Group for Comprehensively Deepening Reforms was slated to become a Central Comprehensively Deepening Reforms Commission, i.e., the Party institution adopts a typical government label ("commission") in a sign that it is directly exercising government functions.

36 Leutert (2018a) mentions a January 2017 SASAC order for central SOEs to revise their corporate charters to include Party building, without, however, providing a source of the order ("Guanyu jiakuai tuijin zhongyang qiye dang jian gongzuo zongti yaoqiu naru gongsi zhangcheng youguran shixiang de tongzhi" (Circular on some matters regarding the acceleration and advancement of the general requirement to include central SOEs' Party building in their charters)); an internet search for the circular was unsuccessful, as was a search of law databases. On the number of SOEs listed in Hong Kong that have already changed their charters see Schumpeter (2018).

37 Also see, for example, Lucas (2018). 
76. The emphasis on "stronger, better, bigger" and on Party control over SOEs has not gone unnoticed outside the PRC and has met with disapproval abroad and a call for a "level playing field." Seemingly in response, Vice-Premier Liu He is reported in the English language press as having said at a conference on 9 October 2018 that it is "utterly important' to increase the vitality of state firms as 'individual market players."' The authority of SOEs' boards of directors to make "significant decisions" pertaining to personnel and compensation was stressed, and minority shareholders are to be better protected. ${ }^{38}$

\section{Case Study: Oil Industry ${ }^{39}$}

77. In the PRC's pre-reform economy, the Ministry of Petroleum Industry controlled all oil exploration, extraction and production through its subordinate SOEs. The ministry set prices for oil products and determined investment allocations, output targets, and product selection.

\section{A. Reform Stages}

78. Reforms in the oil industry proceeded in three stages. First, in the 1980s, line ministries were gradually abolished and their tasks shifted to holding companies, typically involving a transfer of personnel who retained their previous bureaucratic ranks. In the oil industry, the reform created three national oil companies (NOCs) based on an upstream-downstream distinction. Each company was designed as a holding company with formal ownership rights over the individual enterprises under its remit.

79. In 1982, the China National Offshore Oil Corporation (CNOOC) was created specifically to handle all offshore upstream activities. This included offshore exploration, extraction, production, and offshore cooperation with foreign oil companies. The CNOOC holds vice-ministerial rank.

80. In 1983, the China National Petrochemical Corporation (Sinopec) was created as a downstream oil company by merging enterprises with oil-related business that had formerly been under four ministries: petroleum, petrochemicals, textiles, and light industry. Sinopec encompassed all petrochemical industry production, from crude oil refining to oil products, petrochemicals, chemical fertilizers, synthetic resigns, fibers and rubbers. Sinopec was placed under the direct supervision and control of the State Council and holds ministerial rank. Most of Sinopec's production units were separate legal entities, each responsible for maintaining and increasing state assets. Sinopec was responsible, among others, for sector development plans, the pricing of oil products, and the allocation of crude oil to its subsidiaries.

81. In 1988, the Ministry of Petroleum Industry was reorganized into the China National Petroleum Corporation (CNPC), which from then on exercised control over the assets formerly under the ministry and took on many of the formerly ministerial functions. The CNPC was constrained to onshore upstream oil exploration, extraction, and production. The CNPC holds ministerial rank.

38 See Tang and Wang (10 October 2018). The Xinhua News Agency in a Chinese language article posted on the SASAC website (http://www.sasac.gov.cn/n2588025/n2588139/c9678422/content.html, accessed 12 October 2018) chose a somewhat different overall theme to describe what appears the same conference, with a focus on the "central position" of SOEs in the economy.

39 This section is based on a multitude of sources. The academic literature provides the core information and perspectives (but is limited in detail). An English language overview over the development of the petroleum industry can be found in Nolan (2001a, 2014) and Taylor (2012). A large number of newspaper articles and web articles were consulted. Wikipedia at times served to counter-check details. 
82. Most individual enterprises under these three NOCs were independent, incorporated legal persons which largely operated on their own. retained all profits, and entered into joint ventures with multinational companies. The largest of these enterprises developed their own reform plans and business strategies and floated on international stock markets. For example, Daqing (under the CNPC) in the 1990s endeavored to become a global corporation; this included a potential merger with Shanghai Petrochemical Company, a company under Sinopec, in order to combine upstream and downstream operations into a large national company. Daqing in 1997 accounted for two-thirds of the CNPC's post-tax profits (with taxes remitted directly to the Finance Ministry [FM]). In the case of Sinopec, by end-1997 16 subordinate companies had been listed on domestic and international stock markets (Shanghai Petrochemcial Company in 1997 was the first Chinese company to list abroad), with $62 \%$ of their shares owned by Sinopec; the assets of the listed companies accounted for approximately one-fifth of Sinopec's total assets.

83. A key limitation to the development of individual companies was the upstream/downstream divide which made the sale and purchase of crude oil a matter of administrative control by the holding companies and the state. At the same time, profit retention by individual enterprises meant the accumulation of funds with few venues for productive use within the oil industry. Daqing, for example, then chose to diversify. Up to 80,000 people were employed in Daqing's subsidiary companies ranging from property investment to food processing, plastics, garments, textiles, aerospace, and auto components. Total income from diversified business may even have come to rival that from the Daqing oilfield.

84. Listing of companies typically meant restructuring. For example, in the case of Daqing, the listed core company ended up with approximately 106,000 employees, while 180,000 employees were moved into various "service companies." Similarly, when the Shanghai Petrochemical Company prepared for listing in 1993, it separated its core business from its various non-core business activities, thereby reducing employment from approximately 60,000 to 37,000.

85. Listing does not mean independence. Even after the Shanghai Petrochemical Company listed on the Hong Kong stock market in 1997, Sinopec still decided the source, amount, and price of crude oil supplies to the Shanghai Petrochemical Company, and decided on its wage bill. It also collected $55 \%$ of the distributed profits based on the Sinopec ownership share, and possibly a share of retained profits.

86. By the mid-1990s, the attempts by individual companies to expand their business and to break the upstream/downstream divide began to endanger the status of their holding companies (CNPC and Sinopec). This triggered a second wave of reform.

87. In June 1998, senior policymakers ascertained the primacy of the CNPC and Sinopec and decided that the CNPC and Sinopec were to be restructured along geographic lines and to each become vertically integrated. They were to be given complete operational independence with the pursuit of profits as their sole aim. All three NOCs were to pursue a listing on international stock markets. They were also encouraged to compete with each other.

88. Sinopec subsequently transferred 19 petrochemical enterprises to the CNPC, while the CNPC transferred 12 enterprises to Sinopec. All provincial state-owned petroleum companies and their petrol stations were placed under the CNPC and Sinopec. The new Sinopec accounted for approximately $60 \%$ of the PRC's total refining capacity and the new CNPC for much of the remaining $40 \%$; and Sinopec accounted for $30 \%$ of onshore crude production capacity (and more than half of the PRC's output of main petrochemical products) and the CNPC for more than $60 \% .40$ Together, these two companies accounted for $90 \%$ of crude oil production, $75 \%$ of natural gas output, $95 \%$ of oil refining capacity, and $90 \%$ of ethylene cracking capacity. The outcome was an

40 In 1997, the CNPC_-as the upstream company_produced $89 \%$ of the PRC's total oil output. 
oligopolistic market structure for crude oil products and petrochemicals, with limited and administratively managed competition.

89. In a third wave of reform, in April 2000 PetroChina Limited was floated on the New York and Hong Kong stock exchanges as the listed arm of the CNPC. In October 2000, Sinopec Limited was listed on the New York, London, and Hong Kong Stock exchanges. In February 2001, CNOOC Limited, incorporated in Hong Kong (not like PetroChina and Sinopec in the PRC), was listed on the New York and Hong Kong stock exchanges.

90. In all three cases, what was listed was the core business, while a group (or: parent) company retained all non-core assets. The core business included all production assets in oil and petrochemicals. The non-core business included some specialist oilfield engineering services and otherwise non-oil and non-petrochemical businesses such as utilities and social welfare operations-but also "historical burdens" such as non-performing financial claims and redundant personnel-as well as controversial projects such as the CNPC's holdings in Sudan. In the case of PetroChina, the listed company had 480,000 employees while the parent company retained more than a million employees. In the case of Sinopec, the listed company had 400,000 employees compared with 1.12 mio in the old Sinopec. Each listed company sold approximately $10 \%$ of their equity. The flotations raised USD 3.0bn for the CNPC and USD 3.5bn for Sinopec, in contrast to an originally expected range of USD 5-10bn for each.

91. An issue in the preparation for flotation was whether the group company (jituan gongsi)equally: mother company (mu gongsi) —or the 'child' company (erzi gongsi) was to be the entity for flotation. This was resolved in favor of the 'child' company. Nevertheless, the 'mother' company, such as the CNPC Group Company, is the controlling company (konggu gongsi) of the floated (child) joint stock company. The mother company is not simply a 'shell,' and the operational autonomy of the floated company is not unlimited.

92. In 2003, all three NOCs were placed under the newly created SASAC. The outcome is a multi-tier structure "State Council - SASAC - individual group companies (CNPC, Sinopec, CNOOC) - listed companies (PetroChina, Sinopec Limited, CNOOC Limited) - their subsidiaries (some of which may be independently listed)."

\section{B. Idiosyncrasies}

93. To the outside observer, the PRC's listed oil companies may not differ much from their Western competitors: They are formal companies with formal organizational structures, listed on international stock markets. Yet behind this appearance lurk numerous idiosyncrasies.

\section{Pricing}

94. Until the mid-1990s, prices of oil products were state-controlled. Upstream oil prices were liberalized first to closely follow global prices, benefiting the CNPC whenever international oil prices rose. Downstream oil prices remained tightly controlled for longer, and in years when international crude oil prices were low oil-refining became a loss-making business for Sinopec and smuggling boomed. Government subsidies were administered on a discretionary basis, resulting in the CNPC and Sinopec's profits being the residual of government decisions.

95. Historically, an array of price-setting mechanisms was in place, ranging from "State Low Price" to "State High Price," free market prices, and import quotas with international market prices. The "State Low Price" ended in 1993-94 and crude oil prices were moved closer to international prices. After June 1998, domestic crude oil prices were closely linked to international prices; and prices were set once per month in line with changes in the international price. Domestic wholesale prices at the provincial level and below, as well as retail prices, however, remained controlled by 
the state and administered by the CNPC and Sinopec.

96. Today, the National Development and Reform Commission (NDRC) still adjusts the domestic oil price-now every ten days - in accordance with changes in world market prices, and reserves the right to temporarily impose specific price controls for oil products. An elaborate system of subsidies remains in place, extending, for example, all the way to agricultural users, and the three NOCs are asked to smooth price fluctuations internally.

97. When that is not possible, the state provides ad hoc subsidies. For example, in 2008 PetroChina faced losses on the order of USD 18bn in its refining business because it could not pass on the rise in international oil prices to consumers; some of these losses were balanced by profits in its (strong) upstream business. Sinopec was in a weaker position to offset losses and received USD 7.6bn in subsidies. Eventually, both PetroChina and Sinopec were paid monthly subsidies for losses in their refining businesses.

98. As a result of price controls and ad hoc subsidies, it is difficult to ascertain to what extent NOC profits are the outcome of good management and efficient production, or of government price controls and ad hoc decisions. The availability of subsidies also opens the door to rent seeking.

\section{Appointments and appointment authority}

99. The boundary between state and enterprises is fluid. When the Ministry of Petroleum Industry was abolished in 1988, Minister Wang Tao was placed in charge of the CNPC. Bureaucrats and important Party members moved from government and Party institutions into the top echelons of the NOCs.

100. In 2003, Fu Chengyu became the chairman and chief executive officer (CEO) of CNOOC Limited as well as president of the CNOOC group while holding the position of Party Secretary (likely in both, CNOOC Limited and the CNOOC group). In other words, the Party Secretary is both the manager and the chairman of the board, and he controls both the group company as well as the listed company. ${ }^{41}$ The non-transparent group company's interests may well determine the listed company's interests; minority shareholders have no influence.

101. In 2011, Su Shulin moved from his position as chairman of Sinopec to the governor position of Fujian province. He was replaced at Sinopec by Fu Chengyu (previously at the CNOOC). Wang Yilin, vice-president at the CNPC, then filled Fu's seat at the CNOOC. ${ }^{42}$ There is yet a further dimension to the job swaps in that Fu, when appointed head of Sinopec, remained chairman of CNOOC Limited, while Wang was still director of PetroChina after he became chairman of the CNOOC Group. Only later, when the potential conflicts of interest became public, did they resign from their (previous) positions in the listed companies.

102. Given that the NOCs have ministerial rank (vice-ministerial in the case of the CNOOC) and given that they are in majority state ownership, the Party secretary (and thereby CEO and chair of the board of directors) is likely appointed by the Politburo itself, following vetting and selection by the Chinese Communist Party's Organization Department.

\section{Relationship to government/Party}

103. It is not only in the matter of appointment mechanisms that the government/Party reaches deep into the NOCs. As a majority and controlling shareholder in all three listed companies, the

\footnotetext{
41 Sinopec's independent non-executive directors have all worked for the government and are Party members.

42 Job swaps are a common practice. The telecommunications industry went through systematic job rotations.
} 
state/Party controls the operations of the NOCs. Thus, the NOCs serve state/Party interests such as provision of a reliable energy supply at stable prices. The state/Party's interest in stable prices takes precedence over the NOCs' market-based maximization of profit maximization. In the above reported 2008 pricing instance, Jiang Jiemin, chairman of PetroChina, explicitly stated that PetroChina bore the burden of refining losses due to social responsibilities.

104. National energy security and social policy dictated the construction of the West-East Pipeline-delivering natural gas from Xinijiang province to Shanghai-by PetroChina in 20022004 , despite the company's opposition to the project. Foreign firms withdrew from the project because government-imposed price caps on gas delivered to industrial users threatened to undermine the project's economic feasibility. PetroChina can expect to be compensated by the government for losses on the project.

105. When U.S. President Trump visited Beijing in November 2017, the PRC leadership offered that Sinopec would invest USD 43bn in a project for natural gas extraction in Alaska that would create jobs for 12,000 U.S. Americans. For U.S. oil companies such as Exxon Mobil the project, which involved construction of a 1,300 kilometer gas pipeline, was too expensive, and the construction time (10 years), during which there would be no income flows, too long. This means that some activities of Sinope may be determined by the PRC leadership on non-economic grounds.

106. As the PRC's biggest global corporations, the NOCs benefit from a variety of government industrial policies. Such policies include, but are not limited to, government support for establishing international joint ventures, possibly preferential loans from state banks, and the privileged access to international stock markets. ${ }^{43}$

107. While listed companies tend to be under obligation to release certain information, very little is known about the holding companies. The Party/state's oversight of the holding companies via SASAC means the virtually total absence of transparency. Information on the holding companies is treated as highly sensitive. By implication, the performance of the listed companies then does not simply depend on economic factors but on decisions by the non-transparent holding companies, on government-imposed price controls (with ad hoc compensation), and state/Partyimposed investment projects.

\section{Waste and corruption}

108. In the case of Sinopec, its CNY 12mio chandelier in the entrance hall of Sinopec's headquarters in Beijing gained some fame, as did the expense reports of Sinopec managers with millions of US dollars spent on French wines. ${ }^{44}$ In 2009, Chen Tonghai, chairman of Sinopec, received the death penalty (suspended for two years) for taking CNY 198mio in bribes. He reportedly admitted to tampering Sinopec's accounts, embezzling tax revenues, using public funds to bribe other officials, and accepting expensive gifts. News of his arrest at Beijing's airport in May 2007 as he tried to flee the country led to an 8\% drop in Sinopec Limited's share price. In 2017, Wang Tianpu, president of Sinopec Group, was jailed for 15.5 years for accepting bribes of approximately CNY 33.5mio and embezzling state property.

109. CNPC Chairman Jiang Jiemin in March 2013 was transferred to become head of SASAC; in December 2013 he was arrested on corruption charges. In 2015, Liao Yongyuan, the CNPC's president, was placed under investigation, and in 2017 he was sentenced to a prison term of 15

${ }^{43}$ Numerous individual cases, not further explored here, also suggest that Party / government backing allows the NOCs to avoid or rewrite environmental protection standards.

44 This passage draws on Ankenbrand (2018), double-checked against and supplemented by numerous internet sources. 
years.

110. The press labels the PRC's senior oil industry executives the "petroleum faction." Members of this faction came under the investigation of the Party's Central Commission for Discipline Inspection, with many of those investigated linked to the disgraced former security chief and Politburo Standing Committee member Zhou Yongkang.

\section{Profitability and profit surrendering}

111. By 2017, Sinopec and PetroChina (the listed subsidiary of the CNPC) had become the world's two largest oil companies by revenue (Table 5), out-ranking even those international oil companies that had previously far exceeded Sinopec and PetroChina in size. By the 2010s, the CNPC's research and development (R\&D) expenditures even exceeded those of Shell, which previously had the largest R\&D expenditures among all oil companies.

112. The performance of Sinopec and PetroChina (China National Petroleum) lags far behind that of their competitors. Sinopec's return on assets (ROA) in 2017 was $0.4 \%$ and that of PetroChina $-0.1 \%$. The ROA of the next three international competitors was between three and fourteen times higher than that of Sinopec. As regards assets per employee, the ratios of the competitors were between seven and ten times higher, suggesting severe over-employment in Sinopec and PetroChina. If Sinopec and PetroChina as listed companies already suffer from severe over-employment, then the fact that their parent companies in charge of non-core business have another two or three times as many employees than the listed companies suggests potentially highly inefficient operations.

113. It may well be the case that the performance contracts that SOE managers sign with SASAC and which specify compensation relative to, typically, profit objectives achieved, create incentives for SOE managers to pursue profit maximization. But the profitability of Sinopec and PetroChina suggests either that these incentive contracts do not work well (maybe they are trumped by other, career-oriented objectives within the Party) or are defeated by the lack of independence of the NOCs. Thus, the ROA may be low because the NOCs are constrained in the economic activities they can undertake, and the government may choose to use the NOCs as income-earning endeavors and tax them correspondingly.

\begin{tabular}{|c|c|c|c|c|c|c|c|c|}
\hline \multicolumn{9}{|c|}{ Table 5: Fortune Global 500 List 2018, Sinopec and PetroChina } \\
\hline & & $\begin{array}{c}\text { k Revenues } \\
\text { (USD } \\
\text { mio) }\end{array}$ & $\begin{array}{l}\text { Profits } \\
\text { (USD } \\
\text { mio) }\end{array}$ & $\begin{array}{l}\text { Assets } \\
\text { (USD } \\
\text { mio) }\end{array}$ & Employees & $\begin{array}{c}\mathrm{ROA} \\
(\%)\end{array}$ & $\begin{array}{l}\text { Profit per } \\
\text { employee }\end{array}$ & $\begin{array}{c}\text { Assets per } \\
\text { employee } \\
\text { (mio) }\end{array}$ \\
\hline Sinopec & 3 & 326,953 & 1,538 & 346,545 & 667,793 & 0.4 & 2,303 & 0.5 \\
\hline China National Petr. & 4 & 326,008 & -691 & 629,411 & $1,470,193$ & -0.1 & -470 & 0.4 \\
\hline Royal Dutch Shell & 5 & 311,870 & 12,977 & 407,097 & 84,000 & 3.2 & 154,488 & 4.8 \\
\hline $\mathrm{BP}$ & 8 & 244,582 & 3,389 & 276,515 & 74,000 & 1.2 & 45,797 & 3.7 \\
\hline Exxon Mobil & 9 & 244,363 & 19,710 & 348,691 & 71,200 & 5.7 & 276,826 & 4.9 \\
\hline \multicolumn{9}{|c|}{$\begin{array}{l}\text { ROA = return on assets. } \\
\text { Note: Data presumably are for } 2017 .\end{array}$} \\
\hline
\end{tabular}

\section{Mixed ownership reform}

114. Sinopec was one of the first companies to proceed in response to the mixed ownership initiative. In 2014, it opened its wholly-owned subsidiary Sinopec Sales Co., Ltd., to $29.99 \%$ (CNY 
$107.1 \mathrm{bn}$ ) outside ownership via a capital increase. The 25 investors comprise numerous SOEs (such as insurance companies). Four private companies (including Tencent and Hai'er) hold an aggregate $4.58 \%$ stake. Sinopec Sales Co., Ltd. has signed cooperation agreements with ten of its investors, some of which suggest an expansion beyond the core business of the company. The company itself describes its main business as: retail, direct distribution and warehousing of gasoline, kerosene and diesel; natural gas operation for vehicles; retail prepackaged food, bulk food, dairy products; health food; retail of cigarettes and cigars (and another two dozen non-core business items).

115. The CNPC also proceeded with mixed ownership reform. In April 2014, it sold 6 units involved in oil refining, pipeline construction, financing and other areas to private capital. In May 2014 it announced a plan to raise private funds to develop oilfields in the Xinjiang Uyghur Autonomous Region.

\section{CURRENT CHALLENGES OF STATE OWNERSHIP}

116. This section discusses fundamental questions of state ownership in the PRC today. What are the objectives of state ownership? How are ownership, regulation, and restructuring being handled? How are SOEs being supervised?

\section{A. Objectives of State Ownership}

117. The objective of SOEs in the PRC has evolved over time. In the pre-reform period, state ownership served as the pillar of the pre-reform planned economy and polity: half of state revenues were derived from SOEs, and, apart from the government administration and Party, SOEs were the only providers of urban jobs.

118. In the reform period (after 1978), SOEs faced increasing competition by collective-owned (and to a limited extent private) enterprises. At this point, the task of SOEs became codified in the SOE Law of 1988: to, in accordance with the state plan and market demand, develop commodity production, create wealth (chuangzao caifu), increase accumulation, and satisfy the daily increasing material and cultural needs of society.

119. The Company Law (NPC, 29 December 1993, Art. 5), applicable to SOEs organized in the form of companies, declares the objectives of companies to be to increase their "economic results" (jingji xiaoyi) and labor productivity, and to maintain and increase their asset values. "Economic results" remains undefined (financial performance, or even just profitability?).

120. The regulation on the organization of SASAC (State Council, 10 October 2008) in specifying the tasks of SASAC lists one SOE objective: to maintain and increase the value of state assets. ${ }^{45}$ The focus on asset value is a permanent feature of the PRC economy reaching back to the 1950s when fixed asset measures and working capital values were cornerstones of the planned economy. The continued focus on asset values today still reflects a fixation on quantity of capital, in particular physical capital.

121. In none of the available documents does profitability appear as an explicit objective for the SOEs in the PRC. SOEs thus would seem to play by different rules than other market participants

45 An article in The Economist (Schumpeter, 2018) following an interview with SASAC personnel, states: "While SASAC is not explicit about it, it has three, conflicting, objectives: to boost profits and cut debts; to persuade foreigners that SOEs have more autonomy, and to cement the party's muscular role." And "according to SASAC, the Party wants to guide the conduct of SOE bosses but not micromanage. SASAC itself does not want to be responsible for firm's results, but wants to set the boundaries of strategy." 
in the PRC. However, profitability may well have been the unspoken underlying SOE objective for most of the reform period. The SOE reform measures of 1998-2000 were undertaken precisely because SOEs were incurring losses that were deemed too high. Bankruptcies of SASAC enterprises are pursued precisely because these enterprises are not, or cannot become profitable. Restructuring of SOEs under SASAC occurs precisely to turn them into viable (i.e., profitable) enterprises. Zombie enterprises are labeled such precisely because they have experienced three continuous years of losses. And it is profitability and thereby corporate income taxes that is of interest to revenue-starved governments, especially at below-central tiers; SASAC and provincial ASACs also have a direct interest in profitability in that the dividend payments they receive depend on profit.

122. Despite its stated focus on asset values, SASAC in its three-year performance contracts with its subordinate SOEs emphasizes profitability. A contract contains annual and three-year targets, and among the annual targets profit plays a dominant role. Managers are evaluated according to the profitability of their company. ${ }^{46}$

123. Profitability and maximization of asset values are related. To the extent that asset values increase if a firm is profitable and reinvests retained profits, asset values may yet reflect profitability. But that link is tenuous; asset values could equally well be increased by incurring greater debts. The focus on asset values may also be plausible if SOEs were to be privatized eventually, in the sense that a higher value of assets, given the amount of debt, may fetch a higher price.

124. If profitability were the de facto sole objective of SOEs, i.e., if SOEs differ little from private enterprises, one may question why the need for SOEs? Given the continued importance of SOEs to the PRC leadership, one may conclude that there are other reasons for the continued existence of SOEs. Thus, one might for example hypothesize that SOEs play an important role in promoting economy-wide economic growth. But a study by Holz (2011) shows that promoting economic growth via linkage effects is not an SOE objective: SOEs are not strategically located in highlinkage sectors that facilitate economy-wide growth. Instead, the prevalence of SOEs across economic sectors appears to be driven mostly by profitability.

125. Numerous SOE objectives do not appear in official documents but are difficult to deny. ${ }^{47}$ These include the following:

- Creating employment and maintaining employment (an issue of "social stability"), including, especially, for Party members. ${ }^{48}$

- Serving ad hoc government / Party needs, which includes providing a rapid response mechanism in a case such as the U.S. Financial Crisis in 2008.

- Creating job and income opportunities for the highest echelons of government and Party cadres, with leadership positions in SOEs as pre-retirement positions for former

46 Naughton (2010) reports that profit in relation to an agreed target is valued at up to 30 points (out of 100), the rate of return on equity at up to 40 points, and sector-specific targets at a further up to 30 points.

47 The State Council in its 10 October 2008 stipulation on the organization of SASAC contains a catch-all item of implementing "social responsibility" in its enterprises. Hong and Nong (2013) list (and critically analyze) six "missions" of SOEs: enriching the country and strengthening the military, guaranteeing people's livelihoods, national security, international competitiveness, social responsibility, and foundation of the ruling Party.

48 Ankenbrand (2018) suspects that one-quarter of the 40mio employees of SOEs are Party members. This compares with $7 \%$ Party membership across the population. (The cited employment figure of 40mio refers to enterprises, i.e., excludes employment in various state and state-affiliated organs that are not registered as enterprises.) 
government and Party cadres, or assigned to their family members. ${ }^{49}$

- Serving the most varied political objectives, such as being ordered to stop production in August 2016 for the G20 meeting in Hangzhou to enjoy a blue sky.

- Meeting national security needs (including "securing" material resources, and acquiring technology abroad).

- Helping finance economic development in underdeveloped regions of the PRC, and supporting the PRC's security apparatus in "minority"-dominated areasC. ${ }^{50}$

- Serving as "national champions."

- Implementing Xi Jinping's "China Dream," which includes such measures as the "Belt and Road" Initiative, where SOEs may be used to conduct unprofitable economic activities in neighboring countries in pursuit of the Dream, ${ }^{51}$ or they may be prime beneficiaries of profit opportunities created by the Dream. ${ }^{52}$

There also remains an ideological element for having SOEs. State ownership of means of production is one of the four defining elements of socialism (besides "dictatorship of the proletariat," central planning, and "remuneration according to effort"). Abandoning state ownership may be too close for comfort when such ideological elements serve to legitimize Party rule.

126. The multitude of objectives makes it impossible to evaluate SOE performance: Along which criterion, or which combination of criteria, are SOEs to be evaluated? SASAC may well wish to work with a profitability criterion in evaluating the management of central SOEs, but how can it then take into account the various other objectives that SOEs may be asked to fulfill at varying times? In the example of the NOCs, any profitability objective is trumped by government pricing policies, including ad hoc adjustments to prices. The absence of a formal objective-or the presentation of a formal objective (maintain and increase state assets) that is of questionable relevance in practice-means that all evaluation of enterprise performance in the end can only be discretionary and subjective, no matter how detailed and specific SASAC's management contracts may appear.

\section{B. Ownership, Regulation, Restructuring, and Supervision}

127. The introductory section to the State Council's 2008 stipulation on the organization of

49 Leutert (2018b) documents for 864 leader-year observations (2003-2012) that a top executive posting in an SOE tended to be a "one-way exit" into retirement, rather than one step in a revolving door process. Of those who did not leave executive positions in SOEs for retirement, virtually all moved laterally, such as to another (core central) SOE. Mitchell (2018b) quotes David Webb, a Hong Kong-based corporate governance activist, as saying "I don't own SOEs because in general, they are run more for-party than for-profit."

50 See, for example, Feng (2018) in a Financial Times article on the mass incarceration of Uighurs in the PRC's Xinjiang province, which mentions "financial sponsorship from China's state tobacco enterprise" for building new "ethnic unity villages" in the desert (apparently, largely unsuccessful ventures). SOEs are also standard counterparties in the PRC's duikou system, where government and Party organizations as well as SOEs in the richer regions of the PRC are asked to financially, materially, and through the delegation of personnel contribute (as donations) to the economic development in the backward regions.

51 See, for example, the case study of the oil industry above, for an SOE being relegated to undertaking unprofitable activities.

52 For example, Kynge (2018) reports that the Export-Import Bank of China and the China Development Bank, which lend more internationally than the West's six multilateral development banks combined, do not conduct open, competitive tenders for contractors. "This has almost always meant that lucrative contracts were awarded to members of a charmed circle of Chinese state-owned enterprises little incentivized to take local concerns on board." 
SASAC (SC, 10 October 2008) characterizes SASAC as a specially established institution directly under the State Council (guowuyuan zhishu teshe jigou); its Party cell fulfills the tasks assigned by the CCPCC. Under the heading "adjustment of responsibility," SASAC is placed in charge of SOE reform and restructuring, of adjusting the geographic and sectoral distribution of SOEs, and of further advancing state capital in those sectors and areas that are related to national security or that are a "lifeline of the national economy." SASAC is also to strengthen financial supervision, risk control and the auditing of economic responsibility, as well as to improve the appraisal system of management and to promote social responsibility.

128. SASAC's first task is to, in accordance with the Company Law and other relevant laws and administrative regulations, fulfill the responsibility of an investor, to supervise the central stateowned non-financial enterprises, and to strengthen the management of state assets. Subsequently listed SASAC tasks include to:

- maintain and increase the value of state assets;

- implement SOE reform and restructuring while transforming enterprises into modern companies;

- appoint and dismiss the responsible personnel;

- dispatch supervisory boards;

- organize the submission of proceeds from the use of the state's capital (the state capital management budget, discussed above);

- implement national safety regulations;

- take responsibility for the basic administration of state assets, draft laws and stipulations regarding the administration of state assets, issue relevant regulations, and guide and supervise the work of local state asset administrations;

- and fulfill other tasks as assigned by the State Council.

129. These tasks can be grouped under four headings: ownership, regulation, restructuring, and supervision. Two contradictions immediately stand out: First, there is a conflict between being an owner who would, for example, wish to maximize the return on equity, and being a regulator who might be concerned about risks to the national economy potentially triggered by maximization of returns on equity. Second, there is also a potential conflict between the pursuit of professional management of state assets and any political prerogatives that may be imposed by the government / Party (including through political personnel appointments to SOEs). Such conflicts are not addressed by the State Council stipulation of 2008 and remain unresolved.

\section{Ownership and regulation}

130. While SASAC supposedly exercises the powers of an owner over its subordinate enterprises, these powers are de facto highly constricted. First, SASAC does not have the power to decide on the use of SOE profits. It has taken more than a decade for SASAC to extract a modest share of SOE profits via the state capital budget management system. The current level of extraction may well go towards restructuring costs of loss-making SOEs, or to support SOEs that were otherwise not viable.

131. Second, ownership is a fleeting right that may be taken away or altered. Thus, the State Council on 9 November 2017 decreed that 10\% of the ownership of large and medium-sized SOEs (at central and local level) as well as of financial institutions is to be transferred to the Social Security Fund (in the case of central enterprises and financial institutions) and to newly to be established provincial solely state-invested companies with the purpose of funding social security tasks. The program was to start in 2017 with $3-5$ central SOEs and 2 (central) financial institutions, and then to be implemented step by step in 2018. SASAC is in charge of finalizing a program for the transfer of ownership. 
132. Third, SASAC has little authority vis-à-vis SOE managers. Thus, SASAC has no appointment authority over 53 of its SOEs, where top-level appointments are reviewed and approved by the Politburo following vetting by the Party Organization Department. ${ }^{53}$ All key appointments are handled through Party channels, starting with the Party committee within the SOE and continuing with the external (local/provincial/central) Party Organization Department and ultimately a decision by the (external) Party Committee. ${ }^{54}$ At the center, the top-level appointees likely enjoy an equal if not higher bureaucratic rank than even the head of SASAC, and thus are unlikely to submit to directives from SASAC. Top-level positions in central SOEs are at the core of the Party's personnel patronage system and bypass any SASAC "ownership" function.

133. Fourth, SASAC conglomerates are highly opaque organizations with little accountability. SASAC staff, if given access, may not even be qualified to evaluate these firms' operations. SASAC staff were originally derived from government departments that were abolished in earlier administrative reforms and from Party organs; these cadres may have little insight into efficient management of large conglomerates.

134. Fifth, while SASAC SOEs are organized as companies, their internal institutions do not necessarily fulfill the functions associated with them in the West. Thus, attempting to fulfill ownership functions via a board of directors that is run by a Party Secretary appointed by the Politburo may be futile. To the extent that the Party committee/cell within a state company overlaps with the board of directors, SASAC may not have had a say in any of the appointments to the board of directors.

135. For all the same reasons, the regulatory authority of SASAC is weak. As a special institution under the State Council, it lacks the authority previously accorded to line ministries that were in charge of SOEs in a particular sector of the economy. In all three SOE reform policies discussed above that SASAC was involved in-the transformation of non-tradable into tradable shares, the organization of management buyouts, and the establishment of the state capital management budget system-SASAC participated but was not the final authority.

\section{Restructuring and sector focus}

136. A key task of SASAC is the restructuring of its subordinate enterprises. SOE reform issues did not disappear with the creation of SASAC. Rather, they disappeared from public view by becoming in-house issues of SASAC. To the extent that there are loss-making enterprises, or to the extent that SOEs are to be dissolved or merged, these matters now happen behind SASAC's closed doors.

137. Which SOEs are to be retained and which sectors SOEs are to withdraw from have always been a matter of discussion. The $10^{\text {th }}$ Five-Year Plan (2001-2005) delineated the future scope of state ownership in industry (SETC, October 2001). The plan distinguished between five groups of industry sectors:

(i) Military industry remains overwhelmingly state controlled.

(ii) In public goods industries and services as well as in natural monopolies, the state should

53 " 53 " is a widely cited number, which, however, may have changed in the course of enterprise restructuring under SASAC. For example, Leutert (2018a) mentions 53 central "core" firms (or: "important backbone state-owned enterprises") at the start of Xi Jinping first term as Party Secretary in 2012, each at vice-ministerial rank. (Contrary to this source, at least the CNPC and Sinopec are at ministerial rank.)

${ }^{54}$ McNally (2002) provides a detailed description of the selection and appointment process in Shanghai at the time. 
hold a controlling stake.

(iii) In industries of great economic importance for the "strength of the nation," such as the petroleum, automobile, telecommunications, machine building, and high technology industries, state backbone enterprises should continue to hold a dominant position.

(iv) In key high technology areas, the state should adopt a driving function; it need not control production, but provide financing and support basic and applied research.

(v) In "ordinary," competitive sectors, the existing SOEs should focus on improving efficiency, with large enterprises adopting the company system and small and medium-sized enterprises undertaking various property rights reforms; domestic enterprises not owned by the state, as well as foreign enterprises, are invited to participate in the SOE restructuring.

138. Li Rongrong, then head of SASAC, in the mid-2000s summarized the priorities more succinctly as: national security, natural monopolies, public goods or services, important national resources, and key enterprises in "pillar" industries and in high-tech sectors. Each SOE should rank number 1,2 or 3 in its respective markets or exit. The intention was to build strong, competitive firms around core businesses. As investor, SASAC would also not sell down its shares in listed SOEs because the PRC would still need state-owned companies in a "guiding" (zhudao) position, even as the market economy developed. ${ }^{55}$

139. Li Rongrong (2006) elaborated further: In seven defense and "lifeline" industries, the state is to maintain absolute control; these are military industry, power grid, petroleum and petrochemical products, telecommunications, coal, civil aviation, and shipping. ${ }^{56}$ Important "backbone" enterprises should continue to exercise relatively strong control over nine basic industries and pillar industries: equipment, automobiles, information technology, construction, steel, non-ferrous metals, chemicals, geological prospecting, and science. ${ }^{57}$ By 2010 , the above industries must have a number of important backbone enterprises that have a strong influence on the sector's development; the important backbone enterprises in petroleum and petrochemicals, telecommunications, electric power, metallurgy, shipping, and construction are to become worldclass enterprises, those in automobiles, equipment, and electronics are to lay the foundations for becoming world-class enterprises. ${ }^{58}$

140. In a press conference on 19 December 2013, Huang Shuhe, deputy-head of SASAC, stated the following "considerations," distinguishing by degree of state control:

(i) A few (presumably traditional) SOEs and state-owned companies relevant for national security can be in sole state ownership.

(ii) SOEs relevant to the "national economic lifeline" (guomin jingji mingmai) and SOEs in important sectors and key areas can remain in absolute state control.

55 See Naughton (2005 and 2008).

56 In the case of basic infrastructure in the first four industries, the state should have an absolutely controlling stake; in the case of subsidiaries in these four sectors as well as in the case of central enterprises in civil aviation and shipping, the state should also have an absolutely controlling stake; in the case of central enterprises in downstream petroleum products and in value-added services in telecommunications, more reform and restructuring should be undertaken and non-state funding should be sought.

57 Central enterprises are to be important backbone enterprises and sectoral leaders in equipment, automobiles, information technology, construction, steel, and non-ferrous metals. State-owned capital is to hold either absolute control or under certain conditions relative control.

58 As of late 2018, these are indeed sectors where state ownership is dominant or strong, but it is also strong in other sectors, from what one would expect to be competitive sectors to typical public goods sectors such as education, health, and public management (Table 1). 
(iii) Important SOEs in pillar industries and high tech industries, etc., can remain in relative state control.

(iv) When state capital does not need to be in a controlling position, SOEs can be controlled by social capital, or the state may hold shares in the company, or the state can completely withdraw.

141. The discussion of which sectors SOEs are to focus on is ongoing. It keeps moving around the same themes, from national security to lifeline industries, pillar industries, and high tech industries, but fails to clearly identify which SOEs fall into which category (that is then to be treated in a particular way). The 2015 Guiding Opinions asked for classification of SOEs according to their functions (which would then allow differentiated policies). At the national level that classification is still not completed. (Some provincial ASACs, such as that of Shanghai, have proceeded to classify their SOEs.) This is not only a matter of top-level decision making, but also a highly contested topic among enterprises. Managers of individual SOEs are naturally reluctant to see the relevance of their enterprise reduced. ${ }^{59}$

\section{Supervision}

142. The issue of SOE supervision has a long history. Precisely because so much economic power is vested in SOEs and because Party structures supplant formal checks and balances, the use and misuse of state assets have been a recurrent theme throughout the reform period. The issue of supervision is aggravated by the ambiguity in SOE objectives. Absent a singular objective (or clearly delineated set of objectives), mechanisms to identify poor management are lacking. No matter how elaborate the evaluation system for managers may be, if ad hoc instructions force managers' hands any set of evaluation criteria is invalidated.

143. The formal supervisory institution for SOEs is SASAC and the corresponding provincial ASACs. SASAC has three departments in charge of supervision and lists the personnel of 29 supervisory boards for key large SOEs on its website. ${ }^{60}$ But the effectiveness of the supervisory board of formal state-owned companies (which, as of 2018, nearly all SOEs are) is in question when the chair of the supervisory board is a member of the Party committee together with those (managers, directors) that the supervisory board is supposed to supervise. The supervisory board is in no position to supervise the Party secretary, who may well be the chair of the Board of Directors and/or the CEO.

144. Consequently, the SASAC Party committee is equally being assigned a supervisory function (for example, in the 2015 Guiding Opinions), as is the cell of the CCPCC Commission for Discipline Inspection that is attached to the SASAC Party committee. But these personnel are unlikely to be financial or management specialists. They are unlikely to be able to assess corporate strategy, risks and risk management, the viability of control systems, the financial reporting process, or compliance with legislation and regulations. Given how they obtained their position (as trusted Party members through Party channels), they are unlikely to have the interests of shareholders at heart. Supervision can only occur in the broadest sense. It will likely focus on "corruption," with as only tool of supervision the removal of specific, "corrupt" individuals through the CCPCC Commission for Discipline Inspection and no changes to how the company operates.

59 The International Monetary Fund in a fiscal policy paper in 2016 offered a distinction along two criteria: commercial viability (low vs. high) and policy or strategic relevance (low vs. high), with corresponding recommendations for reform. But the formulation of clear categories and preferences in the PRC appears subject to so many conflicting interests (of SOEs, different bureaucracies, and Party factions) with such a variety of types of relevance ("lifeline" economy, "pillar" industries, and "backbone" enterprises) that a decision on classification and corresponding consequences has been out of reach.

60 See http://www.sasac.gov.cn/n2588020/n2877933/index.html, accessed 1 June 2018. 
Given that the formal institutions of companies are supplanted by Party structures, supervision can ultimately only come through the Party personnel administration, and it is limited to personnel control.

145. In a stock market based system, shareholders would ultimately exercise supervision. In the PRC, with the state holding majority or controlling shares across "state-owned" enterprises, the market cannot supervise. Supposedly SASAC-appointed supervisory boards of companies play little role in the face of the dominating role of the Party cell. In a control-based system, banks or founders would exercise supervision, but banks in the PRC are also state-owned, and without authority to play an active role in SOE supervision. ${ }^{61}$ Consequently, SOEs have an extraordinary degree of independence, while at the same time being linked into a Party personnel system that deals in people rather than evaluating and supervising economic decisions.

\section{Corporate Governance: Evaluation}

146. The Organisation for Economic Co-operation and Development (OECD) has issued guidelines on the governance of state-owned enterprises (first version of 2005, revised in 2015). ${ }^{62}$ The guidelines have three aims (2015 edition, p. 11): (i) to professionalize the state as an owner; (ii) to make SOEs operate with similar efficiency, transparency and accountability as good practice private enterprises; and (iii) to ensure that competition between SOEs and private enterprises, where such occurs, is conducted on a level playing field. PRC policy statements regarding SOE reform suggest that at least the first of these three aims-professionalization of ownershipequally applies to the PRC. The second aim applies partially: SOE efficiency levels comparable to private enterprises is inherent in the desire for competitive SOEs; transparency and accountability, however, are not PRC aims. ${ }^{63}$ The third aim, a level playing field between SOEs and the private sector is not an explicit PRC policy and given the multitude of regulations and restrictions, it is hard to pass judgment as to what degree a level playing field exists, sector by sector of the economy.

147. The OECD guidelines comprise approximately 40 items of good governance across several themes. Contrasting the OECD's guidelines on corporate governance of SOEs with PRC practice reveals large gaps: A clear rationale for state ownership of the multitude and diversity of SOEs is lacking, boards of directors do not independently exercise their responsibilities, the ownership entity cannot be held accountable, the state is not an informed and active owner, ownership and other state functions are not separate, some if not most SOEs do not face market consistent conditions regarding access to debt and equity finance, and financial and non-financial transparency is sorely lacking except for listed companies (though information on parent companies, if that exists, is again lacking).

148. At the center of the governance gap appears to be the absence of clearly identified SOE objectives. Without clearly identified objectives, supervision-no matter how it is organizedlacks an unambiguous criterion for evaluation and can only investigate for "corruption" rather than examine activities that fail to further the stated objectives of an SOE. Supervision then is not supervision of management performance but supervision of criminal activities. The institutional

61 See Naughton (2008) for the distinction between market-based vs. control-based systems.

62 The OECD guidelines cover all enterprises that are under the control of the state, "either by the state being the ultimate beneficiary owner of the majority of voting shares or otherwise exercising an equivalent degree of control" (OECD, 2015, p. 14). The PRC terminology "state-owned and state-controlled enterprises" (SOSCEs) covers the same ground.

63 In fact, the opposite appears to hold: The intentional obscuring and withholding of SOE-related information. (See, for example, Mitchell, 2018b.) 
framework in the PRC is aligned: The personnel appointment mechanism ensures the priority of the Party and its policies at all times, ${ }^{64}$ and supervision is exercised by the Party's Commission for Discipline Inspection, targeting corruption.

149. Introduction of the Western company system in the PRC has had little or no effect on corporate governance. Corporate institutions ranging from independent members of the board of directors to strong third-party institutions covering everything from accounting to legal services are either weak, undermined, or missing. What it did achieve was to allow SOEs access to stock markets in the PRC and abroad, i.e., to allow re-capitalization of (listed) SOEs through channels other than the state budget and state bank lending, and thereby to free the state of some of its liability for SOE failures.

150. Perhaps the closest model for the PRC is an Asian model of family-controlled pyramid groups, except that in the case of the PRC, the family is the Party. The Party's objectives are not solely economic, and Party management deals in people rather than in business substance.

151. SASAC, the government institution that nominally owns and regulates SOEs, appears to be a smokescreen for the actual channels of authority and a convenient location where to deposit (and make invisible) SOE problems. The fact that the restructuring of SOEs is still ongoing, twenty years after the 1998-2000 SOE reform program that was to have resolved SOE problems, and despite a second attempt at resolving SOE problems by SASAC in the mid-2000s, suggests that neither the formal institutional arrangement with SASAC, nor the underlying Party structures are successful in tackling economic issues.

\section{CONCLUSIONS}

152. SOE reform in the 1980s was characterized by a move toward separation of government and enterprises, and towards separation of Party and the government. Today, the opposite is the case. The Party openly leads the government, and the dominance of the Party committee in SOEs not only undermines the institutions of the company system but has come to be an important factor even in private and foreign-owned enterprises. This ensures high compliance with central Party directives. The controlling authority of the Party can promote competition and growth by, for example, allowing private actors into industries and by forcing SOEs to compete. But a highly centralized system with top-level policies also has its limitations, experienced, for example, as overcapacity (relevant for steel production starting in 2015) or excessive indebtedness (following the PRC's response to the 2008 U.S. Financial Crisis). The PRC's industrial policy has been predicted to lead to a five-fold overcapacity in robotics manufacturing in 2020 . There would seem to be a fine distinction between the state supporting and promoting certain economic activities and a Party control system that incentivizes SOE leadership to follow top-level directives, even if in disregard of economic fundamentals, and thereby ultimately hampering economic growth.

153. In 2002, McNally was agnostic about improvements to corporate governance. He noted ( $p$. 109) that "since all corporate decisions are either made by a corporation's party committee or handed down through party channels, the system of internal checks and balances within a corporation envisaged by the Company Law has failed to take root." He concluded that the institutional structures through which the Party monitors and controls SOEs have a corrosive

64 SASAC's contracts with SOE management, potentially specifying profit objectives, likely pale in importance compared with the direct chain of command within the Party structure. McNally (2002, p. 109) finds that "managers of state assets thus tend to spend considerable effort presenting the right political image and nurturing good relations with superiors in the party hierarchy. Effectively managing state assets is secondary, especially since there are few negative consequences of economic mismanagement." 
effect on the governance of the majority of SOEs in that they lead to inadequate monitoring of managerial performance, weaken managerial incentives, and exacerbate the lack of transparency, which in turn allows state managers to create their own spheres of autonomy (leading to insider control and corruption). The solution is to "require the party to substantially diminish its authority over state sector executives" (p. 91); "the first step would be to centralize the oversight and management of state holding corporations, including personnel appointments, in one government institution" (p. 113). But that, he concluded, is politically difficult. Today the Party is far from relinquishing control. Rather, reforms have proceeded in the opposite direction, strengthening Party control without resolving the conflicts.

154. Naughton (2010) ponders whether the cost of public ownership may not be acceptable when market failure (including the absence of strong regulatory capacity) is widespread. In such circumstances, competition may be more important than ownership. He argues that the PRC's SOEs compete by design, often in markets structured as dominant-player oligopolies with a competitive (including private) fringe. ${ }^{65}$ Firms in near-monopoly position reap monopoly rents which, under state ownership, are re-invested. Private firms benefit from spill-overs such as when capacity (for example, in infrastructure) moves ahead of demand and creates profit opportunities for all. ${ }^{66}$ One could find many more arguments in favor of SOEs, from reliable tax collection in a system where private enterprises frequently manage to escape taxation to issues of social stability in a country the size of the PRC with weak institutions.

155. Under such circumstances, reliance on the authority of the Party appears indispensable. It is the Party that ensures competition: When the division of the petroleum industry into one upstream conglomerate and one downstream conglomerate turns out to be inefficient, firms are rearranged to create two competing integrated conglomerates. When competition becomes too fierce, as it may have in the telecommunications market with the three firms competing for market share in a price war, the CEOs of the three firms are reshuffled (and the CEOs get the message). Mergers can be enforced top-down to reduce competition or to create giant firms that can improve efficiency and compete internationally. Where central government departments are too weak to enforce national policies and to regulate reliably, and where individual SOEs have built fiefdoms within the state, the Party personnel appointment mechanism allows for immediate corrections, outside any regulatory framework, without need for justification or consistency. (The underlying assumption, though, is that this abstract construct 'Party,' that is seen as in charge, is "good" and knows what is "best.")

156. Reliance on the Party is also indispensable when one realizes that the Party's control over the economy is all-encompassing. By controlling the banking system and major enterprises in the real economy (SOEs), the Party directly controls the basic functioning of the economy with mechanisms of control that far exceed the effectiveness of fiscal and monetary policy (which are also under Party control).

157. The relationship between SOEs and the (state-owned) banks is particularly complex and held together ultimately by Party control. On the one hand, bank lending to SOEs may come with the benefit of an implicit state guarantee for the loan. On the other hand, banks have also been asked to take some of the financial burden off SOEs by swapping debt into equity, rolling over

65 Examples along these lines are competition among the three state telecommunications firms (China Mobile, China Unicom, and China Telecom) and competition among the three centrally owned airlines (Air China, China Southern, and China Eastern).

66 Another characteristic of the PRC's development trajectory has been the absence of a unified vision for economic development. While individual departments may plan (and individual SOEs pursue their own agendas), overall policies develop in response to continuously evolving signals from the economy, including the performance of SOEs. Rules and incentives can be changed at any time, and institutions can be repurposed freely. 
non-performing loans, or writing off loans (typically with subsidies by the finance departments). In a number of instances local banks went bankrupt and were bailed out and restructured by local authorities when SOEs struggled to repay their loans. In other instances, SOEs are brought in to save bankrupt banks, for example by buying non-performing loans at face value. In yet other instances, SOEs or private enterprises are the main shareholders of a local bank and also the bank's biggest clients. ${ }^{67}$

158. State-ownership in the PRC in the final instance is the expression of the Party's control over the economy. In such an environment, strong regulatory capacity with a strong private sector cannot co-exist. The Party makes and adjusts the law. I.e., the Party cannot be subjected to an independent regulatory framework and formal institutions that operate independently of the Party, and cannot submit to market outcomes created by private actors if these outcomes run counter to the Party's prerogatives. From the absolute authority of the Party follows the reliance on the cadre management system that dominates SOE management and also reaches into private enterprises.

159. But the Party, despite its Leninist-authoritarian character, is not a monolithic organization. Given the large number of SOEs (with enterprise numbers in excess of 100,000), individual SOEs can come to behave like powerful families or interest groups (some headed by minister-rank personnel) that block reforms and pursue enterprise-specific or person-specific interests that in turn shape Party policies. ${ }^{68}$

160. The outcome is a corporate governance structure that in its management of SOEs ultimately relies on only one mechanism: the Party appointment system, complemented by the Party's "anticorruption" campaign. SOEs (or SOSCEs) in the PRC are less "state-owned and state-controlled enterprises" than they are "state-owned, Party-controlled enterprises." There is little point recommending adoption of OECD principles of good governance in the presence of an overarching Party priority that does not accord with Western corporate governance principles.

161. Naughton (2010) argues that when the rural-urban transition is complete and when the economy ceases being a pure follower economy, the need to increase efficiency and creativity leads to a turning point. Such a turning point could lead to the establishment of competing sovereign wealth funds, along the lines of the state-owned asset management system since promoted by the 2013 Third Plenum but until today not realized. As Naughton points out (pp. 458f.), "the Party would have to agree that 'one share, one vote' really means that appointments to the Board of Directors, and ultimately appointments of managers, are determined by weighted alliances of different shareholders, and not just by the Party speaking for the dominant government shareholder." But as Party directives and Party Secretary Xi Jinping's statements of the recent years indicate, such a reduction in Party control is not on the horizon.

162. The PRC then is facing the dilemma of having an increasingly sophisticated economy, with an increasingly complex web of economic transactions and developments that are beyond the

67 Funding of such banks frequently comes from sources other than deposits (such as trusts and securities companies), and lending frequently ends up being shadow loans to avoid regulators' lending limits. Wildau and Jia (2018) detail some individual cases. To give just one example of the many possible, complex incentive mechanisms at work, SOEs may be willing to purchase bank loans at face value if that offers them an easy way to then take control of the borrower, where otherwise the SOEs may have been prohibited from expanding into the business of the borrower.

68 For example, the administration of the previous (2002/03-2012/13) Party Secretary Hu Jintao and Prime Minister Wen Jiabao attempted to redistribute income from SOEs to labor, but powerful SOEs and state-owned banks were able to resist, at least until 2007, when the capital management budget system was introduced, initially at practically no cost to enterprises (due to the reduction in the corporate income tax rate). Similarly, a central plan to reduce transportation costs was blocked by state-owned oil companies concerned about their profits. See, for example, Davis (2012) for attempts at redistributive measures being blocked by SOEs. 
planning capability of any planning authority, but with none of the institutions to support such an economy. An increasingly first-world economy is commandeered in what resembles clan fashion. Perhaps the private sector eventually reaches such dominance that state-ownership under Party control fades from importance. But to judge from current policy statements, the reverse appears to be intended, a revival of state ownership. The institutional environment to support efficient, market-based operations remains lacking. Reform of the institutional framework appears severely out of step with the complexity of the economy. Ultimately the Party either establishes the necessary Party-external institutional framework for a modern economy to operate efficiently and grow, or it finds hitherto non-existing Party-internal mechanisms that allow the efficient operation of a modern economy, under Party control. 


\section{REFERENCES}

Ankenbrand, Hendrik. "Der Oelkonzern der Partei" (The Party's Oil Company). Frankfurter Allgemeine Zeitung, 4 July 2018 (p. H5).

Bond, David. "UK Cyber Intelligence Chief Urges West to Engage with China." Financial Times, 24 October 2018.

Brandt, Loren, and Xiaodong Zhu. "Accounting for China's Growth." University of Toronto, Department of Economics, Working Paper 394, 16 February 2010.

CCPCC (Chinese Communist Party Central Committee).

31 October 2004. "Guanyu jiaqiang he gaijin zhongyang qiye dangjian gongzuo de yijian" (Suggestions on strengthening and improving Party building in central enterprises). Issued by the CCPCC Organization Department and the SASAC Party Committee and passed on by the CCPCC General Office.

At http://cpc.people.com.cn/GB/64162/71380/102565/182143/10993484.html, accessed 1 October 2018.

2013. "Guanyu zhongyang qiye dangwei zai xiandai qiye zhidu xia chongfen fahui zhengzhi hexin zuoyong de yijian" (Suggestions on giving full play to the political core role of the Party committees of central enterprises under the modern enterprise system). Issued by the CCPCC Organization Department and the SASAC Party committee and passed on by the CCPCC General Office. Referred to in SASAC Party Committee, 31 May 2016.

. 12 November 2013. "Zhonggong zhongyang guanyu quanmian shenhua gaige ruogan zhongda wenti de jueding" (Decision of the Central Committee of the Chinese Communist Party on Several Major Issues Concerning Comprehensively Deepening Reform). At http://www.gov.cn/jrzg/2013-11/15/content 2528179.htm, accessed 1 October 2018.

24 August 2015. "Guiding Opinions of the CPC Central Committee and the State Council on Deepening the Reform of State-owned Enterprises." At www.gov.cn and Xinhua News Agency, 13 September 2018.

September 2015. "Guanyu shenhua guoyou qiye gaige zhong jianchi dang de lingdao jiaqiang dang de jianshe de ruogan yijian" (Various opinions on maintaining Party leadership and strengthening Party building in deepening SOE reform). Likely issued by the CCPCC or a department thereof, and reported on, for example, in the People's Daily of 21 September 2015, at http://politics.people.com.cn/n/2015/0921/c1001-27610380.html, accessed 1 October 2018.

CCPCC General Office Regulations Office (together with CCPCC Disciplinary Committee Regulations Office, and CCPCC Organization Department General Office). Zhongguo gongchandang dangnei fagui xuanbian (Selected internal regulations of the Chinese Communist Party). Beijing: Falu chubanshe, 2001.

CCPCC Organization Department and SASAC Party Commitee. "Zhongyang zuzhibu, guowuyuan guoziwei dangwei guanyu zhongyang qiye dangwei zai xiandai qiyezhidu xia chongfen fahui zhengzhi hexin zuoyong de yijian" (Opinions of the CCPCC Organization Department and the SASAC Party Committee on giving full play under the modern enterprise system to the political core role of the Party Committee in central enterprises). Document no. 5, 2013.

CEIC. CEIC China Premium Database. At https://www.ceicdata.com/en/products/chinaeconomic-database. 
Chazan, Guy. "Backlash Grows Over Chinese Deals for Germany's Corporate Jewels." Financial Times, 13 March 2018, p. 7.

China Infobank. Internet source (www.chinainfobank.com). "Zhongguo guojia jingmaowei shenhua guoyou qiye gaige yanjiuzu" (SETC research group on deepening SOE reform). 25 June 2001.

Citi (Citi Research Economics Emerging Markets Asia). "Alert: SOE Reform Update - State Council Releases Guidance to Manage State-Owned Financial Capital of Financial Institutions." China Economics Flash, 11 July 2018.

Cui, Zhiyuan. "Partial Intimations of the Coming Whole: the Chongqing Experiment in Light of the Theories of Henry George, James Meade, and Antonio Gramsci." Modern China 37, no. 6 (2011): 646-60.

Davis, Bob. "China Tries to Shut Rising Income Gap." The Wall Street Journal, 10 December 2012.

Dewenter, Kathryn L., and Paul H. Malatesta. "State-owned and Privately Owned Firms: An Empirical Analysis of Profitability, Leverage, and Labor Intensity." American Economic Review 91, no. 1 (March 2001): 320-34.

Feng, Emily. "Crackdown in Xinjiang: Where Have All the People gone?" Financial Times, 4 August 2018. At https://www.ft.com/content/ac0ffb2e-8b36-11e8-b18d-0181731a0340.

Ferrarini, B., and M. Hinojales. "State-owned Enterprises Leverage As a Contingency in Public Debt Sustainability Analysis: The Case of the People's Republic of China." ADB Economics Working Paper Series, no. 534, January 2018.

Fiscal Yearbook. Zhongguo caizheng nianjian (China Fiscal Yearbook). Issued by the PRC Finance Ministry. Beijing: Zhongguo caizheng cazhishe, various years.

Gan, Nectar. "State-owned Enterprises Win 'Unswerving Support' of Xi." South China Morning Post, 29 September 2018, p. A5.

Gatley, Thomas. "Softening Up on SOE Deleveraging." GavekalDragonomics Ideas, 9 August 2018.

Holz, Carsten A.

. China's State-owned Enterprises between Profitability and Bankruptcy. Singapore: World Scientific, August 2003.

. "The Unbalanced Growth Hypothesis and the Role of the State: the Case of China's Stateowned Enterprises. Journal of Development Economics 96, no. 2 (Nov. 2011): 220-38.

Hong, Sheng and Zhao Nong. China's State-Owned Enterprises: Nature, Performance and Reform. The Unirule Institute of Economics, China. Singapore: World Scientific, 2013.

Huang, Philip C.C. "Chongqing: Equitable Development Driven by a "Third Hand"?" Modern China 37, no. 6 (2011): 569-622.

IMF (International Monetary Fund).

. How to Improve the Financial Oversight of Public Corporations. Fiscal Affairs Department, Fiscal Policy Paper, 2016. July 2018.

People's Republic of China: 2018 Article IV Consultation. IMF Country Report No. 18/240,

Industry Statistical Yearbook. Zhongguo gongye jingji tongji nianjian (Statistical Yearbook of China's Industrial Economy). Beijing: Zhongguo tongji chubanshe. Various years. In 1986 titled 
Zhongguo gongye jingji tongji ziliao 1986 (Statistical Material on China's Industrial Economy 1986). Beijing: Zhongguo tongji chubanshe, 1987.

Kynge, James. "China's Belt and Road Difficulties Are Proliferating." Financial Times, 10 July 2018, p. 9.

Lam, W. Raphael, Alfred Schipke, Yuhan Tan, and Zhibo Tan. "Resolving China's Zombies: Tackling Debt and Raising Productivity." IMF Working Paper WP/17/266, November 2017.

Lardy, Nicholas R. Markets over Mao: The Rise of Private Business in China. Washington, D.C.: Peterson Institute for International Economics, 2014.

Leng, Sidney, and Yangpeng Zheng. "Beijing Tries to Play Down 'Made in China 2025' as Donald Trump Escalates Trade Hostilities." South China Morning Post, 26 June 2018. At https://www.scmp.com/news/china/policies-politics/article/2152422/beijing-tries-play-downmade-china-2025-donald-trump (accessed 25 September 2018).

Leutert, Wendy. "Firm Control: Covering the State-owned Economy Under Xi Jinping." China Perspectives, no. 1-2 (2018a): 27-36.

"The Political Mobility of China's Central State-owned Enterprise Leaders." The China Quarterly, no. 233 (March 2018b): 1-21.

Li Rongrong. "Guoziwei: guoyou jingji ying baochi dui qi ge hangye de juedui kongzhili" (SASAC: State-owned economy should maintain absolute control over seven industries). At .http://www.gov.cn/ztzl/2006-12/18/content 472256.htm, accessed 31 July 2018.

Lucas, Louise. "The Big Read. Xi Jinping: The Chinese Communist Party Entangles Big Tech." Financial Times, 18 July 2018.

McNally, Christopher A. "Strange Bedfellows: Communist Party Institutions and New Governance Mechanisms in Chinese State Holding Corporations." Business and Politics 4, no. 1 (2002): 91 115.

Mitchell, Tom.

. "Sharing Your Bed with China Inc Is Risky Business." Financial Times, 24 October 2018a. "China's for-Party Corporations Are Best Kept Out of Portfolios." Financial Times, 28 November 2018b.

Miura, Yuji. "What Is the Future for China's State-owned Enterprises? A Tentative Evaluation of the Effects of Reform on Growth Sustainability." RIM: Pacific Business and Industries 15, no. 57 (2015): 2-35.

Naughton, Barry.

_. "SASAC Rising." China Leadership Monitor 14 (30 April 2005). At https://www.hoover.org/profiles/barry-naughton.

. "SASAC and Rising Corporate Power in China." China Leadership Monitor 24 (12 March 2008). At https://www.hoover.org/profiles/barry-naughton.

. "China's Distinctive System: Can It Be a Model for Others?" Journal of Contemporary China 19, no. 65 (June 2010): 437-60.

"Supply-side Structural Reform: Policy-makers Look for a Way Out," China Leadership Monitor 49 (1 March 2016a). At http://www.hoover.org/profiles/barry-naughton.

. "Two Trains Running: Supply-side Reform, SOE Reform and the Authoritative Personage." $\overline{C h i n a}$ Leadership Monitor 50 (19 July 2016b). At http://www.hoover.org/profiles/barry-naughton. 
NBS database: Dabase at http://www.stats.gov.cn (posted values may change over time due to official revisions).

Nolan, Peter. China and the Global Economy: National Champions, Industrial Policy and the Big Business Revolution. New York: Palgrave, 2001a.

. China and the Global Business Revolution. New York: Palgrave, 2001b.

Chinese Firms, Global Firms: Industrial Policy in the Age of Globalization. Routledge

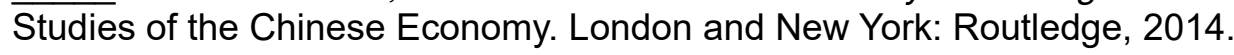

NPC (National People's Congress). "Zhonghua renmin gongheguo gongsifa" (PRC Company Law). $29 \quad$ December $1993 . \quad$ At http://www.360doc.com/content/17/0409/07/2972720 644045278.shtml or (in English) at http://www.china.org.cn/english/government/207344.htm, accessed 18 September 2018. (Revised in 1999, 2005, and 2013.)

OECD (Organisation of Economic Cooperation and Development). OECD Guidelines on Corporate Governance of State-Owned Enterprises, 2015 Edition. Paris: OECD Publishing, 2015.

SASAC Yearbook. Zhongguo guoyou zichan jiandu guanli nianjian (China State(-owned) Asset Supervision and Administration Yearbook). Various years.

SASAC (State(-owned) Asset Supervision and Administration Commission).

. 30 December 2015. "Guanyu guoyou qiye gongneng jieding yu fenlei de zhidao yijian" (Guiding suggestions on the demarcation and classification of SOE functions). Issued by SASAC, Finance Ministry, and NDRC. At http://www.mof.gov.cn/zhengwuxinxi/zhengcefabu/201512/t20151230 1638704.htm, accessed 7 October 2018.

SASAC (State(-owned) Asset Supervision and Administration Commission) Party Committee. "Zai quanmian shenhua guoyou qiye gaige zhong jiaqiang dang de jianshe gongzuo" (On strengthening Party building in comprehensively deepening SOE reform). Qiushi no. 11 (2016), published 31 May 2016. At http://www.qstheory.cn/dukan/qs/2016-05/31/c 1118938354.htm, accessed 28 September 2018.

SC (State Council).

April 2002. (State Council News Office) "Zhongguo laodong he shehui baozhang zhuangkuang" (The state of labor and social security in China). Zhonghua renmin gongheguo guowuyuan gongbao, no. 19 (10 July 2002): 39-46.

10 October 2008. (State Council Office) "Guowuyuan guoyou zichan jiandu guanli weiyuanhui zhuyao zhize neishe jigou he renyuan bianzhi guiding" (Main duties, internal organization, and staffing of the State Council's State-owned Asset Supervision and Administration Commission).

http://www.sasac.gov.cn/n2588025/n2588119/c2688077/content.html.

9 November 2017. "Guowuyuan guanyu yinfa huazhuan bufen guoyou ziben chongshi shebao jijin shishi fang'an de tongzhi" (State Council implementation program for the use of state capital to supplement social security). Guofa no. 49 (2017)

Schumpeter (pseudonym). "Are China's State Giants Reformable? SASAC, the Chinese Agency that Oversees a Hundred or so State-owned Enterprises, Sets Out Its Case." The Economist, 1 March 2018. At https://www.economist.com/business/2018/03/01/are-chinas-state-giantsreformable (accessed 1 June 2018).

SETC (State Economic and Trade Commission; formerly State Economic Commission). "'Shiwu' 
gongye jiegou tiaozheng guihua gangyao" (Outline of the adjustment in the industrial structure during the tenth Five-Year Plan). October 2001. In China Infobank (online database).

Statistical Yearbook. Zhongguo tongji nianjian (China Statistical Yearbook). Beijing: Zhongguo tongji chubanshe, various years.

Tang, Frank, and Orange Wang. "Beijing Directs State Firms to 'Perform Like Normal Enterprises' after Trade Partners' Complaints." South China Morning Post, 10 October 2018. At https://www.scmp.com/economy/china-economy/article/2167738/beijing-directs-state-firmsperform-normal-enterprises-after (accessed 11 October 2018).

Taylor, Monique. 'China's Oil Industry: 'Corporate Governance with Chinese Characeristics.' Chapter 4 in Yi-chong Xu, The Political Economy of State-owned Enterprises in China and India, New York: Palgrave Macmillan, 2012, pp. 69-93.

The US-China Business Council. "China's Strategic Emerging Industries: Policy, Implementation, Challenges, \& Recommendations." March 2013. At https://www.uschina.org/sites/default/files/seireport.pdf, accessed 9 February 2017.

Wang, Dan, and Yanmei Xie, "A Military Embrace Brings Risks for Technology." GavekalDragonomics Ideas, 16 August 2018.

Wang, Orange. "Is Beijing Going Back to the Future with Its Much-hyped 'Made in China 2025' plan?", South China Morning Post, 20 July 2018. At https://www.scmp.com/news/china/economy/article/2154489/beijing-going-back-future-its-muchhyped-made-china-2025-plan (accessed 25 September 2018).

Wildau, Gabriel, and Yizhen Jia. "Regional Lenders: China's Most Dangerous Banks." Financial Times, 31 July 2018.

Wuebbeke, Jost, Mirjam Meissner, Max J. Zenglein, Jaqueline Ives, and Bjoern Conrad. "Made in China 2025: The Making of a High-tech Superpower and Consequences for Industrial Countries." Mercator Institute for China Studies (MERICS) Papers on China, no. 2 (December 2016).

$\mathrm{Xu}$, Xiaonian, and Yan Wang. "Ownership Structure and Corporate Governance in Chinese Stock Companies." China Economic Review 10, no. 1 (Spring 1999): 75-98. 


\section{Appendix 1. State-owned Enterprise Share in Gross Domestic Product}

The assumed state-owned and state-controlled enterprise (SOSCE) share in Table 2 is based on the following considerations. ("SOSCEs" refers to state-owned and state-controlled enterprises and is abbreviated as "SOEs" except when "SOEs" explicitly refers to traditional SOEs.)

Agriculture: Total employment in agriculture is 219.19 mio. Employment in SOEs is 2.614 mio (Finance Ministry data). SOEs are given double weight to account for the likely higher valueadded per employee in SOEs (which are likely concentrated in higher value-added activities).

Mining: Starting point is the share of SOEs in main business revenue of above-norm industrial enterprises. (This share is double-checked against the share in employment and the share in assets, and appears reasonable.) It is assumed that $85 \%$ of value-added in mining is produced in above-norm industrial enterprises, and that no SOE is of below-norm size.

Manufacturing: Same as for mining. The share of value-added in this sector produced by abovenorm industrial enterprises is assumed to be $90 \%$.

Utilities: Same as for mining. The share of value-added in this sector produced by above-norm industrial enterprises is assumed to be $95 \%$.

Construction: The value-added listed in the construction section of the Statistical Yearbook is equal to 0.7735 of the construction value-added listed in the gross domestic product (GDP) section and it is assumed that the difference is produced by non-state enterprises. A breakdown by ownership in the construction section is available for gross output value (in the construction section) with the "state" accounting for a 0.1204 share, collective-owned enterprises accounting for 0.0241 , foreign enterprises for a miniscule share, and the remainder being a 0.8482 residual. It is assumed that the ownership breakdown of gross output value equally holds for value-added. It is assumed that the "state" value reflects only traditional SOEs and that one-third of the implicit residual reflects state-controlled companies (and state joint enterprises). Labor productivity (gross output value per employee) in the "state" sector exceeds average labor productivity, and the derived SOSCE share is therefore multiplied by the ratio of labor productivity in the state sector to total construction labor productivity.

Trade: It is assumed that "above designated size" enterprises (for which some detailed data are available) account for 0.7 of value-added in trade (and that all other units that engage in trade are not state-owned). For "above designated size" enterprises, wholesale and retail trade values are combined, and the share of the state in the "cost of principal business" is used to proxy the share of the state in (unknown) value-added of the "above designated size" enterprises. Lacking a comprehensive state category, the state is taken to comprise the categories traditional SOEs, state joint enterprises, all solely state-owned limited liability companies, one-half of all other limited liability companies, and one-half of all stock companies.

Transport: It is assumed that the data coverage in the transport section of the Statistical Yearbook covers $90 \%$ of transport value-added (with the remainder being by non-state enterprises), and that each employee in the different transport sub-sectors listed in the Statistical Yearbook 
produces the same amount of value-added. With no output or sales data available in the transport section of the Statistical Yearbook, the derivation of the state share is based on the available employment values. It is assumed that the following shares of employees are employees of SOEs: railway 1 (all), road 0.3 , water 0.3 , air 1 , pipeline 1 , loading/unloading and forwarding agency 0.5 , storage 0.5 , post 1 .

Hotels and catering: Identical assumptions to the case of trade (with the two sub-categories hotels and catering in this instance).

Real estate: It is assumed that the real estate section in the Statistical Yearbook covers all real estate units. In terms of employment (the only available relevant variable for the purpose here), only 0.0209 of employment is in "state" enterprises (with additional small shares reported for "collective" and "foreign"); these "state" enterprises are assumed to be traditional SOEs. It is further assumed that one-third of the implicit residual share of 0.9069 consists of statecontrolled enterprises.

Scientific research and technical services: It is assumed that the corresponding section in the Statistical Yearbook covers all relevant units. For the proxied aggregation of the registrationbased data see the section on trade.

For all other sectors-the SOSCE share, lacking relevant data-has been assumed. Data on urban employment (one-quarter of economy-wide employment) by sector with an ownership breakdown into state, urban collective, and "other" was considered. 


\section{Appendix 2. Choice of Performance Indicator}

163. In evaluating economic performance, academic economists tend to focus on some measure of efficiency change, typically "Total Factor Productivity" (TFP) growth, where TFP growth represents that part of output growth that cannot be attributed to capital or labor growth. TFP is then often interpreted as "technology," without, however, providing any rationale for that interpretation. (l.e., it is assumed that technology floats in the air and can be stuck into a piece of pig iron (capital) to yield a computer, a car, or a T-Bar for house construction, depending on need.) High TFP growth, meaning a high growth rate in output that cannot be explained by the growth of capital or labor, is then taken to be a positive development of "technology," and higher TFP levels in one enterprise than in another is taken to represent a higher "technology-level" in the first.

164. For the purpose here, the concept has (at least) two severe shortcomings that argue against its use: (i) In the absence of any rationale for what TFP stands for-it could reflect weather, political enthusiasm, or any other or all of a million causes, and the one thing it cannot reflect is technology, which is embodied in capital and/or labor-interpreting changes in TFP is pointless. ${ }^{69}$ (ii) Even if TFP had any meaning (and it won't be "technology" or "efficiency"), it cannot be compared across enterprises or industries, let alone countries, which each have very different production relationships.

165. In contrast, profitability provides a meaningful measure of performance. (i) Profitability is crucial for enterprise survival. Losses reduce an enterprise's net worth, to the point where the dwindling amount of equity will lead lenders not to extend further loans to an enterprise, possibly leading to illiquidity. Eventually, insolvency and bankruptcy become highly likely. Bankruptcy has effects on employment and economic growth. (Already, an unprofitable enterprise will likely see stagnation and output reduction.) (ii) "Enterprise A is more profitable than enterprise B" is a meaningful statement; profitability is an appropriate measure to compare performance across enterprises, industries, and countries.

166. Relatively high or relatively low profitability opens up possibilities for further exploration and implications. For example, why is high profitability not being competed away? Has the state erected barriers to entry (or reserved to high-profitability industry for certain enterprises only)? Or why do low-profitability enterprises not exit? Does the state provide direct or indirect subsidies (for example, via low interest loans)?

167. Key profitability measures are return on equity (ROE) and return on assets (ROA). ROE is the most meaningful measure of performance: It measures the annual return to the capitalprovider, exactly what profitability means. While equity data are frequently available in PRC statistics, a breakdown of equity with the sub-category of paid-in equity is less frequently available, making it difficult to understand what the variable equity comprises. The alternative measure of profitability is ROA, with asset data widely available and having concrete meaning. A shortcoming of ROA, however, is that the value of assets relative to equity can vary drastically across industries and enterprises. Both, ROA and ROE, are standard measures of economic performance across the finance literature.

69 To illustrate the point with an example: Assume two identical computers (capital goods) except that they contain different processors (processors incorporating different technology levels). If one processor is significantly better (higher technology level) than the other, it will likely fetch a higher price. I.e., the technology difference is captured by the difference in physical capital values (price of a capital good, in this example the price of the computer). But if physical capital values comprise technology levels, then, in a production function estimation, the residual TFP cannot capture technology. 